\title{
A Review of Environment Effects on Nitrate Accumulation in Leafy Vegetables Grown in Controlled Environments
}

\author{
Zhonghua Bian ${ }^{1,2} \mathbb{D}$, Yu Wang ${ }^{2}$, Xiaoyan Zhang ${ }^{3}$, Tao Li ${ }^{1} \mathbb{D}$, Steven Grundy ${ }^{2}$, Qichang Yang ${ }^{1,4}$ \\ and Ruifeng Cheng ${ }^{1, *}$ \\ 1 Institute of Environment and Sustainable Development in Agriculture, Chinese Academy of Agricultural \\ Sciences, Beijing 100081, China; zhonghua.bian@ntu.ac.uk (Z.B.); litao06@caas.cn (T.L.); \\ yangqichang@caas.cn (Q.Y.) \\ 2 School of Animal, Rural and Environmental Sciences, Nottingham Trent University, Nottingham NG25 0QF, \\ UK; wangyu985@yeah.net (Y.W.); steven.grundy@ntu.ac.uk (S.G.) \\ 3 Institute of Industrial Crops, Jiangsu Academy of Agricultural Sciences, Nanjing 210014, China; \\ myfair@yeah.net \\ 4 Institute of Urban Agriculture, Chinese Academy of Agricultural Sciences, Chengdu 610213, China \\ * Correspondence: chengruifeng@caas.cn; Tel.: +86-010-82105983
}

Received: 26 April 2020; Accepted: 26 May 2020; Published: 3 June 2020

\begin{abstract}
Excessive accumulation of nitrates in vegetables is a common issue that poses a potential threat to human health. The absorption, translocation, and assimilation of nitrates in vegetables are tightly regulated by the interaction of internal cues (expression of related genes and enzyme activities) and external environmental factors. In addition to global food security, food nutritional quality is recognized as being of strategic importance by most governments and other agencies. Therefore, the identification and development of sustainable, innovative, and inexpensive approaches for increasing vegetable production and concomitantly reducing nitrate concentration are extremely important. Under controlled environmental conditions, optimal fertilizer/nutrient element management and environmental regulation play vital roles in producing vegetables with low nitrate content. In this review, we present some of the recent findings concerning the effects of environmental factors (e.g., light, temperature, and $\mathrm{CO}_{2}$ ) and fertilizer/nutrient solution management strategies on nitrate reduction in vegetables grown under controlled environments and discuss the possible molecular mechanisms. We also highlight several perspectives for future research to optimize the yield and nutrition quality of leafy vegetables grown in controlled environments.
\end{abstract}

Keywords: nitrate reduction; $\mathrm{HY} 5$; light; temperature; $\mathrm{CO}_{2}$; fertilizer strategy; water management

\section{Introduction}

Nitrogen is a key element for the biosynthesis of nucleic acids, protein, and chlorophyll in plants. Among the various nitrogen sources, nitrate is largely taken up from the soil by plant roots [1]. To ensure the yield of marketable production, nitrate fertilizer is widely applied to crops [2,3]. Due to the increasing demand for inexpensive food and the relatively low cost of mineral fertilizer, overfertilization of nitrogen, especially nitrate fertilizer, has been a common issue in crop production [2,4]. Overfertilization of nitrate not only leads to low nitrogen-use efficiency and accelerates both the eutrophication of water and the acidification of soil but also results in excessive accumulation of nitrates in edible portions of crop plants.

Vegetables play a vital role in the human diet because they are rich in a wide range of beneficial compounds, including vitamins, minerals, and secondary metabolites [5]. However, vegetables, 
especially leafy vegetables, can accumulate extremely high levels of nitrates (usually nitrate level $\geq$ $700 \mathrm{mg} \mathrm{kg}^{-1}$ ) during cultivation [6,7]. Although several recent studies have indicated that a short-term high-nitrate diet can alleviate the risk of high blood pressure and cardiovascular disease in some people older than 60 years [8,9], an increasing number of studies have reported that the consumption of vegetables containing a high nitrate concentration every day poses a threat to human health and can cause gastric cancer and methemoglobinemia in infants and children $[10,11]$. To protect human health, the Joint FAO/WHO Expert Committee suggests that the acceptable and safe daily consumption of nitrate ions should not exceed $0.07 \mathrm{mg} \mathrm{kg}^{-1}$ bodyweight day ${ }^{-1}$ [12]. It has been reported that nitrate intake from vegetables accounts for approximately $80 \%$ of daily intake in the human diet [13]. Therefore, it is essential for food safety to maintain nitrate levels in vegetables below legal limits. In recent years, the regulation of nitrate concentration in vegetables has generated great concern among researchers and farmers $[5,6,14-16]$.

In plants, nitrate accumulation depends on its absorption and metabolism. Some of the root-absorbed nitrates are assimilated in the roots, but most are transported to the shoots and assimilated by nitrate reductase (NR) and other nitrogen metabolism enzymes in plant leaves [17]. The uptake, assimilation, and translocation of nitrates in plants are regulated by multiple internal cues (expression of related genes and enzyme activities) and also by external environmental factors [7]. In addition to better fertilization management strategies, nitrate concentration in vegetables can be reduced through the regulation of the growth environment, thereby promoting the reduction of nitrate into organic nitrogen compounds $[5,7,18]$. Controlled environmental agriculture, or protected horticulture, as it is also known, has been the most prevalent form of horticultural crop production due to its high yield [19]. Greenhouses are the most widely used protected facilities because they create an ideal environment (e.g., light conditions and temperature) for vegetable production. There are approximately 115 countries in the world commercially producing vegetables using greenhouses, and the total area of worldwide greenhouse vegetable production was 473,466 hectares in 2016 [19]. Combined with soilless cultivation techniques (e.g., hydroponics and aeroponics), protected horticulture has been recognized as a promising method for increasing yields in commercial vegetable production [20]. However, excessive nitrate accumulation in vegetables produced under protected cultivation is also a common issue due to unsuitable nitrate fertilization and/or environmental management strategies [21,22].

In recent years, several reviews have summarized the broader aspects of the effects of nitrogen management on nitrogen-use efficiency and nitrate accumulation in crops [2,21-23]. However, reviews concerning the management strategies of nitrate concentration in vegetables produced in controlled environments are relatively limited. Therefore, this review aims to present the current research on decreasing the nitrate concentration in vegetables grown in controlled environments. We also discuss some possible mechanisms concerning nitrate concentration regulation in vegetables and proposed perspectives for future research.

\section{Nitrate Assimilation and Accumulation in Vegetables in Response to Light Conditions}

Nitrate assimilation in plants starts with the reduction of nitrate to nitrite by NR in the cytoplasm. The resulting nitrite is reduced to ammonium by nitrite reductase (NiR) localised in chloroplasts or in plastids in the roots [24] (Figure 1). Light is one of the main factors regulating plant growth and development (Figure 2), as light not only provides energy for driving photosynthesis but also serves as a transduction signal for triggering the expression of related genes. Light stimulates nitrate reduction by inducing NR-related gene (NR) expression, increasing NR activity, and providing available reductants [25]. In plant leaves, the reductants used for nitrate assimilation are produced from photosynthetic electron transport [26], whereas in the roots, these reductants stem from the process of mitochondrial respiration and the pathways of malate and pentose phosphate [27]. After being received by the photosynthetic antenna complex in plant leaves, the absorbed light energy is transferred and stored as ATP and NADPH by the electron and proton transfer complex. Apart from primarily being used for carbon dioxide $\left(\mathrm{CO}_{2}\right)$ fixation, approximately $25 \%$ of the resulting ATP and 
NADPH will be used for nitrate assimilation in plants $[28,29]$. Thus, excessive accumulation of nitrates in plant tissues frequently occurs under poor light conditions [23].

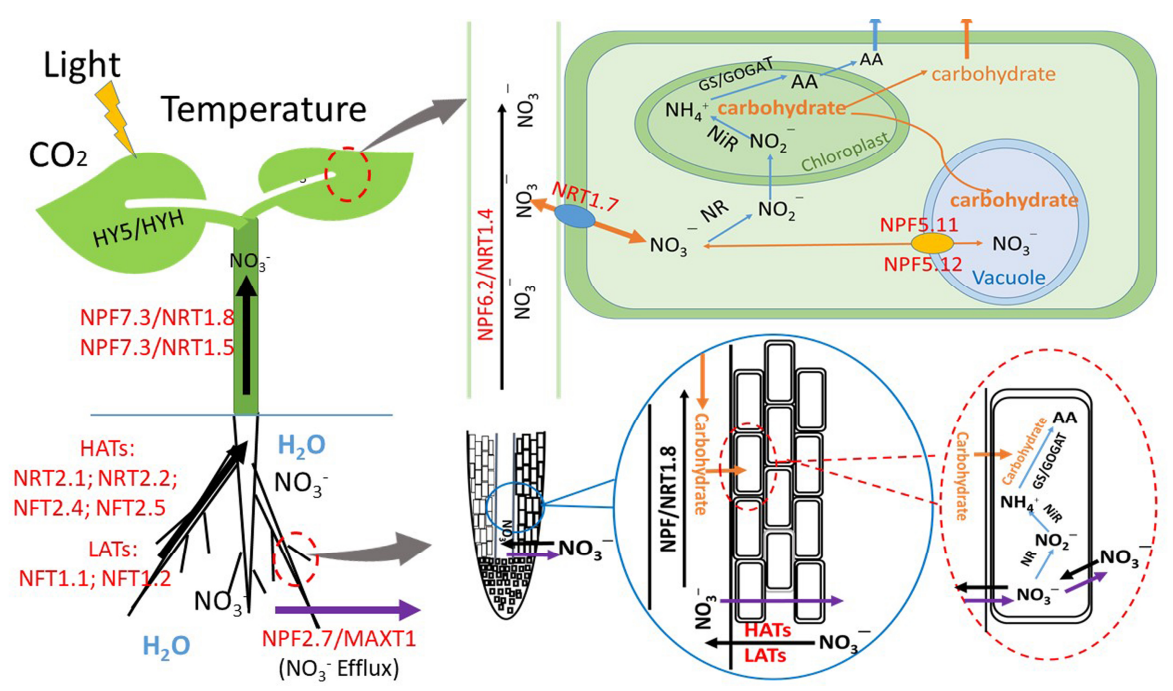

Figure 1. Schematic representation of nitrate absorption, distribution, and assimilation in plants and the function of environmental factors. Light conditions, temperature, and $\mathrm{CO}_{2}$ affect nitrate uptake, distribution, and assimilation in plants [7]. HATs, high-affinity transport system. LATs, low-affinity transport system. NRT1 and NRT2 family members are involved in nitrate uptake and transport [24,30,31]. NR and NiR, nitrate reductase and nitrite reductase, respectively; GS/GOGAT, glutamine synthetase/glutamine-2-oxoglutarate aminotransferase; AA, amino acid. " $\longrightarrow$ " represents $\mathrm{NO}_{3}{ }^{-}$efflux; " $\longrightarrow$ " represents $\mathrm{NO}_{3}{ }^{-}$influx and transport in plant roots and stems. " $\longrightarrow$ " indicates $\mathrm{NO}_{3}{ }^{-}$metabolism. " $\longrightarrow$ " indicates carbohydrate transfer; " $\longleftrightarrow$ " represents $\mathrm{NO}_{3}{ }^{-}$transfer among plant cells.

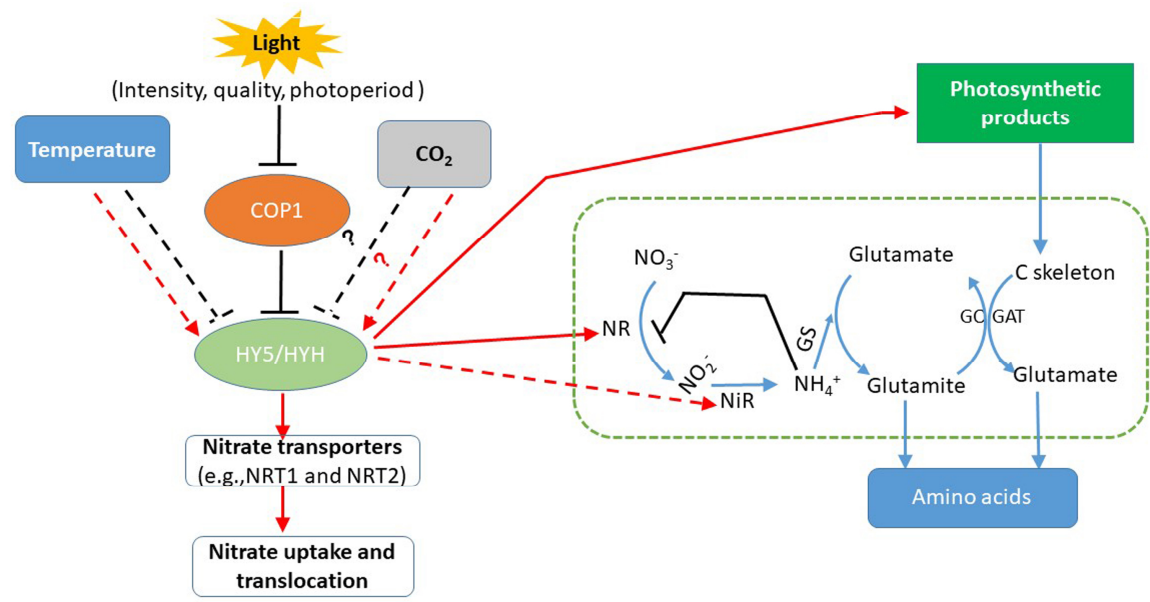

Figure 2. A simplified model of the environmental regulation of nitrate absorption and assimilation in plants. HY5/HYH, the basic leucine (bZIP) transcription factor HYH ELONGATED HYPOCOTYL 5 and its homolog. COP1, the ubiquitin E3 ligase CONSTITUTIVE PHOTOMORPHOGENIC 1, which is involved in the light-related control of nitrate transport and assimilation through interactions with HY5/ $\mathrm{HYH}$ [32]. $\mathrm{CO}_{2}$, cold and heat stress can exert effects together with the light response via the $\mathrm{HY} 5 / \mathrm{HYH}$ pathway $[31,33,34]$, but the mechanism through which temperature stress or other environmental factors, such as $\mathrm{CO}_{2}$, regulate nitrate transportation and assimilation is unclear. " $\longrightarrow$ " represents nitrate assimilation under the reduction of nitrogen-metabolizing enzymes. " $\longrightarrow$ and $-->$ " indicates defined and presumed positive regulation. "- and $--\mid \cdot "$ represents defined and presumed inhibition, whereas "?" indicates a speculation. 
Supplementary light by artificial light sources is widely used to regulate plant growth, phytochemical concentrations, and nitrate concentration in vegetables produced in controlled environments $[6,14,16]$. Following the rapid development of light-emitting diode (LED) technology, LEDs have become a viable and innovative alternative to conventional horticultural lighting because LEDs offer unique advantages such as a high energy-use efficiency, long lifespan (approximately 10,000 h), lower heat-put, and flexible spectral control [6]. The application of LEDs as either a sole source of lighting (e.g., closed-type plant factories and growth chambers) or as supplemental lighting, whether alone or mixed with conventional light sources (e.g., fluorescent and high-pressure sodium lamps), enables horticulturists and farmers to regulate the nitrate concentration in vegetables through light condition management in protected facilities [6]. In general, the effects of light on the uptake, assimilation, and distribution of nitrates can be categorized as related to light intensity, duration, or spectra (Figure 2).

\subsection{The Effects of Light Intensity}

Light intensity has profound effects on the nutritional quality of vegetables. In greenhouses, the amount of daylight received can be reduced by $30 \%$ or more due to the occlusion of the greenhouse structure. Low light intensity is the primary limiting environmental factor for vegetable growth and nutrient improvement in the greenhouse during winter. This is also a problem during the summer period due to the overcast skies [35]. Increasing light intensity within a certain range can induce the activity of nitrate metabolism enzymes and provide more energy for nitrate assimilation [36]. For instance, under different nitrate supplementation conditions, the nitrate concentration in lettuce (Lactuca sativa var. butterhead) leaves significantly decreased when the light intensity of red and blue LED light (red:blue $=4: 1$ ) increased from 60 to $210 \mu \mathrm{mol} \mathrm{m}^{-2} \mathrm{~s}^{-1}$ [37]. Before harvest, supplemental blue LED light increased the growth and nutrients of pak choi (Brassica rapa) grown in the greenhouse, while the nitrate concentration decreased as the blue light intensity increased from 0 to $150 \mu \mathrm{mol} \mathrm{m}{ }^{-2}$ $\mathrm{s}^{-1}$ [38]. Samuolienè et al. [39] used mixed LEDs (those emitting at 455, 638, 665 and $731 \mathrm{~nm}$ ) with different light intensities to treat Brassica microgreens. The results showed that the nitrate concentration in the microgreens decreased by $37.7 \%-84.5 \%$ with increasing light intensity from 110 to $545 \mu \mathrm{mol} \mathrm{m}{ }^{-2}$ $\mathrm{s}^{-1}$. Perez-Lopez et al. [40] studied the interacting effects of light intensity and $\mathrm{CO}_{2}$ concentration on the phytochemical compounds of lettuce grown in a growth chamber. Under an ambient $\mathrm{CO}_{2}$ atmosphere (approximately $400 \mu \mathrm{mol} \mathrm{mol}^{-1}$ ), the nitrate concentration in green-leaf and red-leaf lettuce markedly decreased by $25 \%$ and $86 \%$, respectively, while the soluble sugar concentration increased by $241 \%$ and $41 \%$ when light intensity increased from 400 to $700 \mu \mathrm{mol} \mathrm{m}^{-2} \mathrm{~s}^{-1}$. Additionally, the researchers found that elevated $\mathrm{CO}_{2}$ levels enhanced the positive effects of light intensity on nitrate reduction in lettuce. This may have occurred because the regulatory effects of light intensity-induced NR expression are closely linked to photosynthetic products [25]. It has been reported that the transcripts of NR in Arabidopsis seedlings under low light intensity are comparable to those under high light intensity when sucrose is present in the growth medium, but sucrose did not induce $N R$ expression under darkness [41]. Furthermore, the increased carbohydrates under high light intensity and elevated $\mathrm{CO}_{2}$ can act as carbon skeletons for ammonium $\left(\mathrm{NH}_{4}{ }^{+}\right)$assimilation via the Gln synthetase-Glu synthase cycle (Figure 2), thereby reducing the negative feedback regulation of $\mathrm{NH}_{4}{ }^{+}$accumulation to nitrate assimilation in higher plants [42].

The basic leucine zipper (bZIP) transcription factors ELONGATED HYPOCOTYL 5 (HY5) and HY5 HOMOLOG (HYH) are central regulators of nitrate assimilation in plants [32]. The expression of HY5 is light-intensity-dependent, and high light intensity promotes HY5 accumulation [33]. Previous studies have shown that HY5 positively regulates light-induced NR activity and coordinates nitrogen and carbon acquisition by affecting NR and nitrate uptake-related gene expression [43,44]. Furthermore, under low-light-intensity conditions, the shortage of sucrose impairs HY5-induced NR expression in plants, and, in turn, limits nitrate reduction in plant leaves [45]. In addition, there is no advantage for nitrate assimilation in plant leaves under low-light conditions because of the competition of reductants 
between $\mathrm{CO}_{2}$ fixation and nitrate reduction [46]. In addition to directly serving as a nutrient source, nitrates can also function as osmoticums under low-light conditions, leading to excessive nitrate accumulation in plants [47]. Overall, in controlled-environment growth facilities, better light intensity regulation using artificial light sources could pave a new way to producing leafy vegetables with low nitrate concentration. However, further investigations concerning the molecular mechanism of light intensity in the regulation of nitrate assimilation under controlled environments are still needed.

\subsection{The Function of Light Duration or Photoperiod}

Photoperiod or light duration is another vital environmental factor regulating plant flowering, morphogenesis, and metabolism. The extension of light duration or modification of the photoperiod using artificial light sources can increase carbohydrate synthesis, which stimulates nitrate assimilation by providing a continuous supply of reductant energy and carbon skeletons [48]. After being taken up from the soil and transported into different organs, nitrates are generally stored in the vacuole in the dark [49]. During the daytime or under light conditions, nitrates stored in the vacuole are exported to the cytosol via members of the nitrate transporter 1 (NRT1)/peptide transporter (PTR) family (NPF), including NPF5.12 and NPF1.2, and are reduced by NR [50,51]. Thus, harvesting at the end of the light period has been recommended as a way of producing vegetables with low nitrate concentration [52]. When lettuce was grown under red $(638 \mathrm{~nm})$ light via LEDs under a day/night temperature of 21/17 ${ }^{\circ} \mathrm{C}$ and light intensity of $150-160 \mu \mathrm{mol} \mathrm{m}{ }^{-2} \mathrm{~s}^{-1}$, continuous light (CL) for 22 days was beneficial for decreasing the nitrate concentration in 'Solvano' baby leaf lettuce, whereas it led to excessive nitrate accumulation in 'Multired 2' and 'Multired 4' red-leaf lettuce [52]. Zhou et al. [53] reported that CL for $48 \mathrm{~h}$ using a mixture of red and blue LEDs (red:blue $=4: 1$ ) with a photosynthetic photon flux density (PPFD) of $200 \mu \mathrm{mol} \mathrm{m} \mathrm{m}^{-2} \mathrm{~s}^{-1}$ significantly reduced the nitrate concentration in hydroponic lettuce. This may partially be attributed to the fact that CL promotes stable HY5 protein accumulation and activation [33]. The presence of HY5 activates the expression of NR-rated genes and concomitantly increases NR activity to promote nitrate assimilation in plants under CL [54]. However, Bian et al. [6] found that when hydroponic lettuce was grown under CL delivered by different spectral compositions of LEDs, the nitrate concentration in the lettuce leaves cyclically fluctuated, and the lowest nitrate concentration was observed after CL for $24 \mathrm{~h}$. When the duration of CL exceeded $24 \mathrm{~h}, \mathrm{CL}$ led to a decrease in NR activity and downregulation of NR and NiR expression, which resulted in a decrease in nitrate reduction and, in turn, caused a re-accumulation of nitrates in the lettuce leaves [6]. These results indicate that other mechanisms may be involved in the regulation of nitrate assimilation in vegetables under CL conditions. Jonassen et al. [55] demonstrated that the expression of $N R$ but not other nitrate assimilation-related genes was activated by HY5 and HYH. Under long-term CL, these products of HY5/HYH-induced NR, such as nitrite, nitric oxide, and reactive oxygen species, are toxic to nitrate assimilation as a consequence of the negative feedback on the transcription of $N R$ and activity of NR [56,57] (Figure 2). In addition, the shoot-to-root-translocated HY5 under CL can induce NRT2.1 expression to facilitate nitrate uptake [44], which, to some extent, aggravates nitrate accumulation in plant leaves exposed to long-term CL. In summary, the regulation of the photoperiod or light duration using artificial light sources can be an effective strategy to reduce the nitrate concentration in vegetables. However, in terms of reducing nitrate concentration in vegetables in the greenhouse or closed-type plant factories through light duration management, the vegetable species and other light parameters (light intensity and spectra) should also be considered.

\subsection{The Function of Light Spectra}

Compared with light intensity and light duration, the effects of light spectra on nitrate assimilation in plants are more complex (Table 1). NR is the rate-limiting enzyme that catalyzes the first step of nitrate assimilation. The activity of NR and expression of NR are sensitive to light spectra $[58,59]$. 
Table 1. Effects of LED light spectra on nitrate metabolism in leafy vegetables.

\begin{tabular}{|c|c|c|c|c|c|c|}
\hline & \multicolumn{3}{|c|}{ Lighting Condition } & \multirow{2}{*}{$\begin{array}{l}\text { Vegetable Species or } \\
\text { Varieties }\end{array}$} & \multirow[b]{2}{*}{ Nitrate Metabolic Effects } & \multirow[b]{2}{*}{ Reference } \\
\hline & Light Spectra & 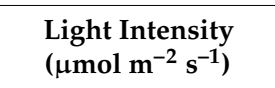 & Light Duration & & & \\
\hline & $\begin{array}{l}\text { UV-A }(383-426 \mathrm{~nm})+\text { red } \\
(599-644 \mathrm{~nm}) \text { and blue } \\
\quad(435-489 \mathrm{~nm}) \text { light }\end{array}$ & $\begin{array}{l}\text { UV-A LEDs: } 30.3 \\
\text { Red LEDs: } 111 \\
\text { Blue LEDs: } 158.7\end{array}$ & $18 \mathrm{~h}$ light $/ 6 \mathrm{~h}$ dark & Lettuce (var. crispa) & Nitrate decreased by $300 \mathrm{mg} \mathrm{kg}^{-1}$ & [60] \\
\hline $\begin{array}{l}\text { UV-A light } \\
(315-402 \mathrm{~nm})\end{array}$ & $\begin{array}{l}\text { UV-A }(366,390 \text {, and } 402 \mathrm{~nm}), \\
+ \text { combination of red }(638 \text { and } \\
665 \mathrm{~nm}), \text { blue }(447 \mathrm{~nm}) \text { and } \\
\text { far red }(731 \mathrm{~nm}) \text { light }\end{array}$ & $\begin{array}{l}\text { UV-A LEDs: } 6.2 \text { and } \\
\text { 12.4, } \\
\text { Blue LEDs: } 21 \\
\text { Red LEDs: } 122 \\
\text { Deep red LEDs: } 155 \\
\text { Far red LEDs: } 2.2\end{array}$ & $16 \mathrm{~h}$ light $/ 8 \mathrm{~h}$ dark & $\begin{array}{l}\text { Microgreens of basil } \\
\text { (Ocimum basilicum L., } \\
\text { var. Sweet Genovese), } \\
\text { beet (Beta vulgaris L., } \\
\text { var. Bulls Blood) and } \\
\text { red pak choi (var. } \\
\text { chinensis, Rubi) }\end{array}$ & 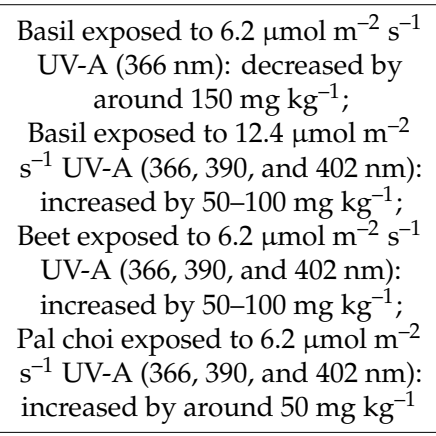 & [61] \\
\hline $\begin{array}{l}\text { Blue LED light } \\
\text { (400-492 nm) }\end{array}$ & $\begin{array}{c}\text { Blue light }(450 \mathrm{~nm}), \\
+ \text { white }(400-700 \mathrm{~nm}) \text { light }\end{array}$ & $\begin{array}{l}\text { Blue LEDs: } 30 \\
\text { White LEDs: } 170\end{array}$ & $16 \mathrm{~h}$ light $/ 8 \mathrm{~h}$ dark & $\begin{array}{l}\text { Lettuce (var. crispa } \\
\text { 'Green Oak Leaf') }\end{array}$ & $\begin{array}{l}\text { Nitrate in leaves decreased by } \\
\text { about } 200 \mathrm{mg} \mathrm{kg}^{-1}\end{array}$ & [62] \\
\hline \multirow{4}{*}{$\begin{array}{l}\text { Green LED light } \\
(492-577 \mathrm{~nm})\end{array}$} & $\begin{array}{l}\text { Green light }(505 \text { or } 530 \mathrm{~nm})+ \\
\text { high pressure sodium lamp } \\
\text { (HPL) light }\end{array}$ & $\begin{array}{l}\text { Green LEDs: } 30 \\
\text { HPL: } 170\end{array}$ & $16 \mathrm{~h}$ light $/ 8 \mathrm{~h}$ dark & $\begin{array}{c}\text { Baby leaf lettuce: red } \\
\text { leaf (var. Multired 4), } \\
\text { green leaf (var. } \\
\text { Multigreen 3), light } \\
\text { green leaf (var. } \\
\text { Multiblond 2) }\end{array}$ & $\begin{array}{l}\text { Nitrate in red leaf and light green } \\
\text { leaf lettuce decreased by } 5666 \\
\text { and } 4705 \mathrm{mg} \mathrm{kg}^{-1} \text { under } 505 \mathrm{~nm} \\
\mathrm{LED}, 5452 \text { and } 9785 \mathrm{mg} \mathrm{kg}^{-1} \\
\text { under } 530 \mathrm{~nm} \text { LED light; nitrate } \\
\text { increased by } 3568 \text { and } 249 \mathrm{mg} \\
\mathrm{kg}^{-1} \text { under } 505 \text { and } 530 \mathrm{~nm} \mathrm{LED}\end{array}$ & [63] \\
\hline & $\begin{array}{l}\text { Green light }(522 \mathrm{~nm})+\text { white } \\
\quad(400-700 \mathrm{~nm}) \text { light }\end{array}$ & $\begin{array}{l}\text { Green LEDs: } 30 \\
\text { White LED: } 103\end{array}$ & $16 \mathrm{~h}$ light/8 h dark & $\begin{array}{l}\text { Lettuce (var. crispa } \\
\text { 'Green Oak Leaf') }\end{array}$ & $\begin{array}{l}\text { Nitrate decreased by around } 200 \\
\mathrm{mg} \mathrm{kg}^{-1}\end{array}$ & [62] \\
\hline & $\begin{array}{l}\text { Green light }(530 \mathrm{~nm})+ \\
\text { combined red }(660 \mathrm{~nm}) \text { and } \\
\text { blue }(450 \mathrm{~nm}) \text { light }\end{array}$ & $\begin{array}{c}\text { Green LEDs: } 33.33 \\
\text { Blue LEDs: } 33.33 \\
\text { Red LEDs: } 133.34\end{array}$ & $\begin{array}{c}\text { Illumination for } 24 \mathrm{~h} \\
\text { before harvest }\end{array}$ & $\begin{array}{l}\text { Lettuce (var. } \\
\text { Butterhead) }\end{array}$ & $\begin{array}{l}\text { Upregulated NR related gene } \\
\text { expression; increased NR } \\
\text { activity; decreased nitrate by } \\
\quad 80-111 \mathrm{mg} \mathrm{kg}^{-1}\end{array}$ & {$[6,14]$} \\
\hline & $\begin{array}{l}\text { Green light }(494-565 \mathrm{~nm})+ \\
\text { combined red }(599-644 \mathrm{~nm}) \\
\text { and Blue }(435-489 \mathrm{~nm}) \text { light }\end{array}$ & $\begin{array}{l}\text { Green LEDs: } 44.7 \\
\text { Blue LEDs: } 108.3 \\
\text { Red LEDs: } 147\end{array}$ & $18 \mathrm{~h}$ light $/ 6 \mathrm{~h}$ dark & Lettuce (var. crispa) & Nitrate decreased by $400 \mathrm{mg} \mathrm{kg}^{-1}$ & [60] \\
\hline
\end{tabular}


Table 1. Cont

\begin{tabular}{|c|c|c|c|c|c|c|}
\hline & \multicolumn{3}{|c|}{ Lighting Condition } & \multirow{2}{*}{$\begin{array}{c}\text { Vegetable Species or } \\
\text { Varieties }\end{array}$} & \multirow[b]{2}{*}{ Nitrate Metabolic Effects } & \multirow[b]{2}{*}{ Reference } \\
\hline & Light Spectra & 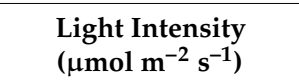 & Light Duration & & & \\
\hline $\begin{array}{l}\text { White LED } \\
(400-700 \mathrm{~nm})\end{array}$ & $\begin{array}{l}\text { White light }(400-700 \mathrm{~nm})+ \\
\text { combination of red }(660 \mathrm{~nm}) \\
\text { and blue }(454 \mathrm{~nm}) \text { light }\end{array}$ & $\begin{array}{l}\text { Total light intensity: } \\
\qquad 210\end{array}$ & $16 \mathrm{~h}$ light $/ 8 \mathrm{~h}$ dark & $\begin{array}{l}\text { Boston lettuce (var. } \\
\text { capitate) }\end{array}$ & $\begin{array}{l}\text { Nitrate decreased by } 20 \mathrm{mg} \mathrm{kg}^{-1} \\
\text { (dry weight) }\end{array}$ & [16] \\
\hline $\begin{array}{c}\text { Red LED } \\
(600-700 \mathrm{~nm})\end{array}$ & $\begin{array}{l}\text { Red light }(638 \mathrm{~nm})+\mathrm{HLP} \\
\text { and nature light }\end{array}$ & $\begin{array}{c}\text { Red LEDs + HPL (90) } \\
+ \\
\begin{array}{c}+ \\
\text { Nature light intensity } \\
=300\end{array}\end{array}$ & $\begin{array}{l}\text { Illumination for } 3 \\
\text { days before harvest }\end{array}$ & $\begin{array}{c}\text { Spinach, parsley } \\
\text { (Petroselinum crispum } \\
\text { Mill.), dill } \\
\text { (Anethumgraveolens) }\end{array}$ & $\begin{array}{l}\text { Reduced nitrate in spinach, } \\
\text { parsley, and dill decreased by } \\
\text { 206, 566, and } 1811 \mathrm{mg} \mathrm{kg}^{-1} \\
\text { respectively }\end{array}$ & [64] \\
\hline $\begin{array}{l}\text { Yellow light } \\
(577-597 \mathrm{~nm})\end{array}$ & $\begin{array}{l}\text { Yellow light }(596 \mathrm{~nm})+\text { white } \\
\text { light }(400-700 \mathrm{~nm}) \text { light }\end{array}$ & $\begin{array}{l}\text { Yellow LEDs: } 30 \\
\text { White LEDs: } 103\end{array}$ & $16 \mathrm{~h}$ light/8 h dark & $\begin{array}{l}\text { Lettuce (var. crispa } \\
\text { ‘Green Oak Leaf) }\end{array}$ & $\begin{array}{l}\text { Nitrate in leaves increased by } \\
\text { around } 200 \mathrm{mg} \mathrm{kg}^{-1}\end{array}$ & [62] \\
\hline \multirow[t]{2}{*}{$\begin{array}{l}\text { Far-red (735nm and } \\
\text { infrared light }(850 \mathrm{~nm})\end{array}$} & $\begin{array}{l}\text { Far-red light }(735 \mathrm{~nm})+\text { cool } \\
\quad \text { fluorescent lamp }\end{array}$ & $\begin{array}{c}\text { Far-red LEDs: } 86 \\
\text { Cool fluorescent lamp: } \\
187\end{array}$ & $\begin{array}{l}\text { Illumination for } 5 \\
\text { days before harvest }\end{array}$ & $\begin{array}{l}\text { Spinach (var } \\
\text { 'Whitney'). }\end{array}$ & $\begin{array}{l}\text { Nitrate excessive accumulation } \\
\left(0.12 \text { mmoles } \mathrm{g}^{-1}\right) \text { by } 10 \text { times } \\
\text { compared with cool fluorescent } \\
\text { lamp only }\left(0.01 \mathrm{mmoles}^{-1}\right)\end{array}$ & [65] \\
\hline & $\begin{array}{l}\text { Infrared light }(850 \mathrm{~nm})+ \\
\text { White light }(400-700 \mathrm{~nm})\end{array}$ & $\begin{array}{l}\text { Infar-red LEDs: } 30 \\
\text { White LEDs: } 103\end{array}$ & $16 \mathrm{~h}$ light $/ 8 \mathrm{~h}$ dark & $\begin{array}{l}\text { Lettuce (var.crispa } \\
\text { ‘Green Oak Leaf) }\end{array}$ & $\begin{array}{l}\text { Nitrate in leaves increased by } \\
\text { about } 160 \mathrm{mg} \mathrm{kg}^{-1}\end{array}$ & [62] \\
\hline
\end{tabular}




\subsubsection{Red and Blue Light}

Among the different light spectra, red $(600-700 \mathrm{~nm})$ and blue light $(400-500 \mathrm{~nm})$ not only are disproportionately absorbed by foliar pigments to drive photosynthesis but also are perceived by photoreceptors to regulate metabolism in plants by triggering downstream gene expression $[66,67]$. Thus, red and blue wavelengths have been considered as the most efficient light sources for vegetable production in protected facilities. Compared with blue light, red light shows higher efficiency at inducing NR activity and reducing nitrate concentration in higher plants [68]. Similar effects of red-light-induced NR activity have been reported in etiolated barley and maize leaves [69]. Furthermore, preharvest supplementation of red LED light $(638 \mathrm{~nm})$ for 3 days significantly reduces nitrate concentration and concomitantly enhances concentrations of secondary metabolites and carbohydrates in different leafy vegetables produced in the greenhouse [64]. These results suggest that a red-light-dependent increase in NR activity may be common among plants. The red light regulation of NR activity is currently believed to be mediated by phytochrome photoreceptors through transcriptional and posttranslational regulation of NR [59]. HY5/HYH is necessary for high NR expression under red and far-red light, and PhyA and PhyB play pivotal roles in red- and far-red light-induced NR expression and NR activity [41]. Recent studies have explored the molecular mechanism of the red-light-mediated activation of NR expression. The regulatory cascade of phyA/phyB-COP1-HY5/HYH is thought to be involved in red-light-induced nitrate assimilation through the regulation of NR activity and NR expression [59]. In plants, nitrate reduction is also regulated by $N R$ at the posttranslational level. Red light signaling can reverse the dephosphorylation of NR, thereby promoting nitrate assimilation in plant leaves [70]. However, the mechanism of phytochrome-mediated signaling in the regulation of this reversible process remains unknown.

The effects of blue light on nitrate uptake and utilization in plants appear to be much weaker than those of red light. Monochromatic blue light is known to increase the overall nitrogen concentration in plants and promote the distribution of nitrates to plant leaves, which leads to excessive accumulation of nitrate in radish leaves compared with the accumulation in plants exposed to red light [58]. However, when combined with other light spectra, blue light shows positive effects on decreasing nitrate concentration and concomitantly enhances phytochemical accumulation in vegetables. Compared with white LED light only, adding blue LED light to white light was more effective at reducing the nitrate concentration in hydroponic lettuce [62]. These results are consistent with the results of Qi et al. [71], who found that blue fluorescent light significantly reduced the nitrate concentration in spinach (Spinacia oleracea L). It is well known that nitrate assimilation has a strong relationship with the photosynthetic capability of plant leaves [25] and that carbohydrates stimulate nitrate assimilation by providing reductant energy and carbon skeletons [7] (Figure 2). Under the same light intensity $\left(210 \mu \mathrm{mol} \mathrm{m} \mathrm{m}^{-2} \mathrm{~s}^{-1}\right)$ and photoperiod $(12 \mathrm{~h})$ conditions, a combination of red, blue, and white LED light was more effective at reducing the nitrate concentration in lettuce grown in a hydroponic system [16]. This phenomenon was presumed to occur because the broad spectral energy of the red light and blue light in the mixed red, blue and white light contributed to nitrate assimilation in the lettuce plants. According to Osterlund et al. [72], cryptochromes, which are blue light receptors, are involved in nitrate assimilation through the regulation of the COP1-dependent degradation of HY5 upon illumination with blue light. Phytochromes, which can weakly absorb blue light in addition to red and far-red light, may also be involved in blue-light-mediated NR activity and NR expression [73]. Glutamine synthetase (GS) is another core enzyme of nitrogen metabolism in plants. Blue light was reported to be involved in the regulation of GS-related gene (GS) expression at the transcriptional and translational levels via phytochromes [74]. Therefore, when combined with other light spectra, blue light may enhance nitrate assimilation by upregulating $N R$ and GS transcriptions and concomitantly enhancing NR and GS activities through all or part of the phytochrome-mediated signaling pathway [59,74]. However, until now, the molecular mechanisms by which blue light is involved in the regulation of nitrate assimilation are still not fully understood. 


\subsubsection{Green Light, UV Light, and Far-Red Light}

In recent years, increasing numbers of studies have shown that other light spectra, including those of green light and UV light, have profound effects on mediating photosynthesis, phytochemical anabolism, and nitrate assimilation in plants [6-8]. Green light has positive functions in promoting nitrate reduction in plants when supplemented with other light spectra or natural light (Table 1). For example, the supplementation of high-pressure sodium lamps $\left(170 \mu \mathrm{mol} \mathrm{m}^{-2} \mathrm{~s}^{-1}\right)$ with $30 \mu \mathrm{mol} \mathrm{m}{ }^{-2} \mathrm{~s}^{-1}$ green $(505 \mathrm{~nm})$ LED light markedly reduces the nitrate concentration and concomitantly enhances the carbohydrate accumulation in lettuce grown in the greenhouse [63]. Similar results were also reported by Chen et al. [62]. With the widespread application of artificial lighting in protected cultivation, CL has been identified as a potential method to increase crop production as well as an effective way to shorten the crop breeding period [75,76]. However, long-term CL induces photodamage and leads to decreases in both crop yield and nutritional quality [77]. Recent studies have shown that adding green light to red and blue LED light can alleviate CL-induced photodamage by upregulating PsbA expression to facilitate the de novo synthesis of the $\mathrm{D} 1$ protein and enhance nitrate assimilation in hydroponic lettuce by increasing NR activity and triggering the upregulation of NR expression [14,78]. Based on these results, it is assumed that green light is involved in the regulation of nitrogen metabolism and enhances the plant abiotic stress tolerance of plants. This view is further supported by a recent study by Bian et al. [79]. However, the underlying molecular mechanisms of green light inducing NR activity and NR expression in vegetables are still unknown.

Unlike green LED light, far-red light has been shown to induce the dephosphorylation of NR through phytochrome-mediated signaling, which results in the inactivation of NR [70]. Consistent with this, the addition of far-red (735 nm) LED light to cool-white fluorescent lamps leads to a 10-fold excessive nitrate accumulation in spinach plants (Spinacia oleracea L. 'Whitney') compared with that in plants grown under cool-white fluorescent lamps only [65]. Similarly, yellow (596 nm) and infrared $(850 \mathrm{~nm})$ LED light supplementation with white LED light led to excessive nitrate concentration in hydroponic lettuce [62]. Because of the occlusion of the covering material, the composition and intensity of UV light (200-400 nm) in the greenhouse are significantly different from those under outdoor conditions. UV light, especially UV-B (280-315 nm) and UV-A (315-400 nm) light, has generated great concern by researchers due to its unique function in plant photomorphogenesis and phytochemical metabolism $[79,80]$. However, there is fierce controversy regarding the effects of UV light on plant photosynthesis, growth, and nitrate reduction [80-83]. UV-A (315-400 nm) was reported to reduce the nitrate concentration in hydroponic lettuce [60]. Brazaityte et al. [61] used UV-A with three different wavelengths (366, 390, and $402 \mathrm{~nm}$ ) combined with two irradiation levels (6.2 and $12.4 \mu \mathrm{mol} \mathrm{m}^{-2} \mathrm{~s}^{-1}$ ) to treat microgreens. The researchers found that the effects of UV-A on the nitrate concentration in the microgreens varied among species and were mediated by the wavelengths and light intensities of UV-A. In addition, previous studies have suggested UV-B exposure has damaging effects on the photosynthetic capability of a range of species $[84,85]$. Excessive UV-B light exposure could induce a reduction in the maximum photochemical efficiency of PSII, leading to decreases in the synthesis of NADPH and ATP, which limits the photosynthetic energy used for nitrate reduction [86,87]. UV-B exposure was reported to limit nitrate assimilation, which may be a consequence of UV-B-induced inhibition of NR activity and impairment of the absorption or distribution of nitrate in plants [88,89]. In Spirodela polyrhiza, UV-B exposure led to the downregulation of $N R$ expression as well as marked decreases in the activities and contents of NR, NiR, GS, and glutamate synthase (GOGAT) [90]. No direct evidence exists showing that UV-B is directly involved in nitrate uptake or distribution, but UV-B can activate HY5 expression in plants [91]. However, the UV-B photoreceptor UVR8 was shown to increase the stability of COP1 by interacting with the COP-SPA1 complex, which leads to the destabilization of the HY5 protein [92]. These results suggest that UV-B has the opposite effect on the accumulation of HY5 transcription and HY5 protein stabilization. These results indicate that the negative effect of UV-B exposure on nitrate assimilation occurs at the transcriptional and posttranscriptional levels as well as at the protein level. 
However, it is still unclear how UV-B irradiation exerts its effects on HY5-regulated nitrate uptake and assimilation in vegetables.

In summary, the differences in light spectra on reducing the nitrate concentration may lie in the fact that the uptake, assimilation, and distribution of nitrate under different light spectra involve complex regulatory networks, which include both transcriptional and posttranscriptional mechanisms of photosynthesis and nitrate assimilation $[44,93]$. Additional studies are still needed to clarify the molecular mechanisms of light spectra on nitrate uptake and utilization in vegetables.

\section{Nitrate Uptake, Distribution, and Assimilation in Response to Growth Temperature}

Temperature is another important environmental factor for plant growth, development, and reproduction. The effects of temperature on plants can be categorized into air temperature and soil temperature. An optimum temperature can not only enhance photosynthetic capability by regulating the key enzyme activities of $\mathrm{CO}_{2}$ fixation but also profoundly affect nitrate uptake, distribution, and assimilation in plants [94] (Figure 1). Greenhouse-grown plants often encounter extreme conditions from chronic and abrupt heat stress during hot summer months [95] or cold stress during off-season cultivation [96]. Heat stress can sharply decrease NR activity and disrupt nitrate assimilation in plants [97]. For instance, raising root-zone temperature leads to the excessive accumulation of nitrate in hydroponic lettuce [30]. Compared with relatively low soil temperature $\left(10^{\circ} \mathrm{C}\right)$, relatively high soil temperature $\left(18^{\circ} \mathrm{C}\right)$ enhances nitrate absorption and leads to the excessive accumulation of nitrate in the roots of radish [31]. Previous studies have shown that a great portion of absorbed nitrate is assimilated in the roots under low temperatures [34]. Under weak light conditions, low temperature not only led to marked decreases in the activities of NR, GOGAT, and GS but also resulted in a low nitrate accumulation in the leaves of tomato [98]. This indicates that, in addition to the inhibition of nitrate reduction, low temperature impairs nitrate uptake and translocation in plants. The translocation of nitrates from the roots to the shoots is regulated by both environmental and intrinsic factors. NRT1.1, NRT1.2, NRT2.1, and NRT2.2 have been demonstrated to be involved in nitrate uptake from the soil into root cells $[99,100]$, while NRT1.5 and NRT1.9 are responsible for root-to-shoot nitrate transport [24]. The transcription factor HY5 is dynamic in plants and plays a central role in nitrate uptake, translocation, and assimilation. A shoot-to-root mobile HY5 has been shown to coordinate carbon and nitrate acquisition and carbohydrate-photosynthate-induced NRT2.1 expression and nitrate uptake in plant roots [44]. Cold stress $\left(4^{\circ} \mathrm{C}\right)$ or heat stress $\left(42{ }^{\circ} \mathrm{C}\right)$ for $24 \mathrm{~h}$ not only leads to the downregulation of BjNRT1.1, BjNRT1.2, and BjNRT1.5 but also results in severe downregulation of BjNR1, BjNR2, and BjNiR1 in Brassica juncea L., which resulted in dysfunction in nitrate uptake and assimilation [101]. However, it has been reported that both low-temperature treatment and short-term heat shock treatment positively enhance the stabilization of the HY5 protein $[102,103]$. Therefore, under cold and heat stress, how HY5 exerts its effects on nitrate uptake and assimilation remains unclear. In summary, extreme temperatures not only inhibit plant growth but also lead to excessive nitrate accumulation in plants. A suitable temperature regulation strategy is needed to guarantee the production of vegetables with a low nitrate concentration.

\section{Nitrate Assimilation and Accumulation in Response to Elevated Carbon Dioxide Concentration}

Carbon dioxide $\left(\mathrm{CO}_{2}\right)$ is necessary for photosynthesis. It is predicted that the atmospheric $\mathrm{CO}_{2}$ concentration will increase to about $800 \mu \mathrm{mol} \mathrm{mol}^{-1}$ by the end of this century. The response of plants to increased $\mathrm{CO}_{2}$ is directly connected with their nitrogen status [104]. Nitrate assimilation is one of the most important physiological responses of plants and the sink size of nitrogen plays a vital role in determining the nitrate assimilation response to elevated $\mathrm{CO}_{2}[105,106]$. Previous studies have reported that compared with nitrogen sink-limitation vegetables, some vegetables which have large nitrogen sink organs showed different responses of nitrate uptake and assimilation to elevated $\mathrm{CO}_{2}[106,107]$. It is reported that increasing $\mathrm{CO}_{2}$ levels markedly decreased the leaf nitrate concentration in sweet 
pepper plants under salt stress [108]. Under elevated $\mathrm{CO}_{2}$ and unlimited nitrate supply conditions, the increased synthesis and activity of NR coincides with an increase in photosynthesis induced by elevated $\mathrm{CO}_{2}$ [109]. Larios et al. [110] reported that a short-term increase in $\mathrm{CO}_{2}$ increased carbohydrate levels and concomitantly reduced the nitrate concentration in cucumber leaves by enhancing NR activity and expression of NR-related genes. Plant photosynthesis and leaf nitrogen sink activity are closely coordinated together. The increase in carbohydrates under elevated $\mathrm{CO}_{2}$ could further promote the transcription and posttranslational regulation of $N R$, increasing nitrate assimilation [111]. In addition, the enhanced photosynthesis induced by elevated $\mathrm{CO}_{2}$ can provide more carbon skeletons and energy for $\mathrm{NH}_{4}{ }^{+}$assimilation. Consequently, nitrogen assimilation would be more efficient in some plants under elevated $\mathrm{CO}_{2}$ conditions compared with ambient $\mathrm{CO}_{2}[105,111]$.

However, some studies have also shown that elevated $\mathrm{CO}_{2}$ leads to a substantial decrease in NR activity and directly inhibits nitrate assimilation in the leaves of a variety of $C_{3}$ plant species, such as wheat and Arabidopsis [104,112]. These differences in the effects of elevated $\mathrm{CO}_{2}$ on nitrate assimilation may be due to the distinct impact of sink-limitation of nitrogen among species [106]. Nitrate assimilation in plants proceeds only when the availability of reduced ferredoxin exceeds the requirement for NADPH synthesis. Under elevated $\mathrm{CO}_{2}$ conditions, when the atmospheric $\mathrm{CO}_{2}$ concentration is greater than the saturation point, the amounts of reductant and ATP generated by the photochemical process cannot meet the requirements of $\mathrm{CO}_{2}$ fixation [113]. The competition for reductants between nitrates and $\mathrm{CO}_{2}$ fixation inhibits nitrate assimilation under elevated $\mathrm{CO}_{2}$ conditions [114]. In plants, the transcription factor HY5 coordinates photosynthetic carbon fixation and nitrogen metabolism, which enables homeostatic maintenance of the carbon-nitrogen balance in dynamic environments [44]. To date, there has been no evidence that $\mathrm{CO}_{2}$ is directly involved in the regulation of $H Y 5$ expression and the stabilization of the HY5 protein. It is possible to speculate that elevated $\mathrm{CO}_{2}$ may affect nitrate uptake and assimilation through involvement in the HY5-mediated regulation of nitrates. Enriching $\mathrm{CO}_{2}$ levels is a common strategy for increasing the yield and nutritional quality of vegetables grown in control environments. However, in terms of reducing the nitrate concentration and enhancing yield, $\mathrm{CO}_{2}$ enrichment should be combined with other environmental regulatory activities, including temperature and light management, and the variation in nitrogen sink size between vegetable species, thereby balancing nitrate assimilation and $\mathrm{CO}_{2}$ fixation in vegetables grown under controlled environments.

\section{Nitrate Assimilation and Accumulation in Response to Fertilizer Management}

Recently, increased demand for organic food with high and natural nutrients has promoted the development of organic agriculture. In contrast to mineral fertilizer that directly provides nitrates, organic fertilizer gradually releases its nitrogen content, which limits the excessive accumulation of nitrate in vegetables [115]. However, the high quality of vegetables in organic agriculture is always at the expense of yield loss and a longer growth period. There is great pressure on agriculture to increase food production to feed a continuously increasing global population and concomitantly protect the environment and conserve natural resources [116]. However, because of the depletion of natural resources, deterioration of environmental conditions and crop yield loss caused by the unpredictability of extreme weather events, achieving simultaneously high nitrate-use efficiency and high crop productivity has become a challenge [117]. These limitations of current agriculture have emphasized the urgent need to develop optimal fertilizer strategies to meet the demands of food security and safety, as well as environmental protection.

In the past few decades, many fertilizer management strategies have been investigated by researchers in terms of reducing the nitrate concentration in vegetables grown in controlled environments. A reduction in nitrate concentrations in nutrient solutions significantly decreased the accumulation of nitrates in hydroponic lettuce [118-120]. In addition, reducing the ratio of nitrate to other nitrogen sources or replacing nitrate ions with chlorides led to a $20 \%-40 \%$ decrease in the leaf nitrate concentration of hydroponically cultivated vegetables [121,122]. However, nitrate concentration 
reduction by a limited nitrate supply often results in yield losses, especially when nitrate starvation is not accompanied by the regulation of other environmental factors that affect plant growth and nitrate assimilation [36,37]. Henriques and Marcelis [123] reported that decreasing light intensity could mitigate the yield loss of lettuce caused by nitrate deprivation. However, the mechanism underlying this phenomenon is still unclear.

In addition to traditional nitrate deprivation, the exogenous application of certain substances has positive effects on decreasing the nitrate concentration of vegetables. Lei et al. [124] reported that the exogenous application of selenium $\left(0.5 \mu \mathrm{mol} \mathrm{L}^{-1}\right)$ significantly decreased nitrate concentration in hydroponic lettuce via enhancing the activities of nitrogen metabolism-related enzymes. Furthermore, foliar nutrition solution with urea (1\%) and molybdenum (Mo, $1 \mathrm{mg} \mathrm{L}^{-1}$ ) significantly reduced nitrates in lettuce produced in the spring season, while foliar application of benzyl adenine $\left(5 \mathrm{mg} \mathrm{L}^{-1}\right)$ was more efficient in decreasing nitrate concentration in lettuce grown in polytunnels in summer-autumn [125]. Moncada et al. [126] reported that adding Mo $\left(0.5,1.5\right.$, and $\left.3.0 \mu \mathrm{mol} \mathrm{L}^{-1}\right)$ to nutrient solutions significantly reduced the nitrate accumulation in lettuce, escarole, and curly endive plants grown in a hydroponic floating system. The positive effect of Mo on nitrate reduction may lie in the fact that Mo is fundamental to the function of NR and consequently mediates nitrate metabolism in plants $[127,128]$. Similar to Mo, another micronutrient element, iron (Fe), plays a crucial role in nitrate assimilation, as Fe acts as a metal cofactor of enzymes involved in nitrate metabolic pathway. A deficiency of Fe in nutrition solution strongly affected nitrate metabolism by limiting NR activity and downregulating $N R$ transcripts in the leaves of cucumber [129]. These results indicate that optimal micronutrient management could be an effective way to produce high-quality vegetables with low nitrate concentration.

In recent years, the use of biostimulants, organic extracts with bioactive molecules such as amino acids and vitamins, has been a common practice in sustainable agriculture [130]. Colla et al. [131] reviewed the positive effects of protein hydrolysates as biostimulants on reducing nitrates in a wide range of vegetable species, such as radish, lettuce, swiss chard, and spinach. Similarly, Amanda et al. [132] reported that foliar applications of a biostimulant (Actiwave ${ }^{\circledR}$, Valagro SpA) at a concentration of $6 \mathrm{~mL} \mathrm{~m}^{-2}$ positively reduced the nitrate concentration in lettuce grown in plastic tunnels. It should be noted that the effect of biostimulants on nitrate metabolism in leafy vegetables is species/various-dependent and is also affected by the dose and the time of application [133]. The positive function of biostimulants on nitrate reduction might be elicited by the downregulation of nitrate transporter genes as well as increasing the transcript levels of related genes involved in the nitrogen metabolism pathway, such as NR and NiR [134,135].

Although many different strategies have been proven to be effective and have been used in reducing nitrates in vegetables, these current conventional fertilizer management strategies could not fundamentally solve the issue of inefficient use of nitrogen fertilizer by crops, which leads to major economic losses for farmers and causes serious environmental problems. In plants, the excessive accumulation of nitrates is mainly a consequence of an imbalance between nitrate absorption and reduction. Plants absorb more nitrates from the soil than is required for their growth, especially when subjected to overfertilization of nitrates [136]. Precision nitrogen management can pave a new way to reduce agricultural inputs and concomitantly alleviate the negative environmental impact of modern agriculture, which can enhance agricultural sustainability from economic and environmental aspects [137]. These precision fertilizer management strategies should be based on the comprehensive consideration of the cross-talk among nitrate supply, environmental factors, and genetic differences in plant species, which affect the uptake, assimilation, and distribution of nitrates in plants. However, at the current stage, the lack of sensors for real-time, rapid, and accurate determination of nitrate concentration in plants and soil/ nutrition solution has limited the application of precise nitrogen fertilizer management in vegetable production in controlled environments [138]. 


\section{Nitrate Uptake, Distribution, and Accumulation in Response to Water Quality and Irrigation Management}

Irrigation regimes not only affect the yield but also the uptake, distribution, and accumulation of nitrates in crops grown in controlled environments. For instance, deficit irrigation and overirrigation lead to excessive nitrate accumulation in wild rocket grown in the greenhouse because of the negative effects on NR activity induced by water shortage and root hypoxia caused by excessive water in the rhizosphere [139]. However, Koyama et al. [140] found that appropriate rhizosphere drought stress decreased the nitrate concentration by $18 \%$ without impairing the final yield of lettuce through lowering the water level of the nutrition solution in hydroponic systems. These conflicting results may be due to the different growth methods and nitrogen management involved, which affect the absorption and metabolism of nitrates in different species of vegetables.

Because of the scarcity of water resources, treated wastewater and saline water have been used for irrigation in many countries, especially in arid and semiarid areas. The reuse of wastewater and saline water can alleviate the water scarcity of agricultural production but their side effects on crop growth and quality should not be ignored [141,142]. For example, irrigation with treated wastewater led to a significant increase in nitrates in pack choi due to the high concentration of nitrates in the treated wastewater even after treatment with membrane bioreactors [143]. Saline water has negative effects on plant growth, but leads to a decrease in nitrate accumulation in lettuce grown under greenhouse conditions [144]. This may be attributed to the competition of the same anion channel between nitrates and chloride $\left(\mathrm{Cl}^{-1}\right)$ at the site of xylem parenchyma cell membranes [145]. In Arabidopsis, nitrates and $\mathrm{Cl}^{-1}$ share the same anion channels, which are encoded by AtNPF2.4 and AtNPF2.5 (Figure 2). The high $\mathrm{Cl}^{-1}$ condition leads to the downregulation of NPF2.4, which limits the loading of $\mathrm{Cl}^{-1}$ and nitrate into the xylem, thereby restricting the root-to-shoot transfer of both nitrates and $\mathrm{Cl}^{-1}$, while the upregulation of NPF2.5 accelerates nitrates and $\mathrm{Cl}^{-1}$ efflux from the roots $[146,147]$. Taken together, irrigation regimes and water conditions should not be ignored in vegetable production under control environments. An optimal irrigation regime based on water conditions could be an effective way to produce low nitrate vegetables and concomitantly achieve water-saving in vegetable production in controlled environments.

\section{Conclusions}

It is well known that nitrate metabolism and accumulation constitute a complex process that is subject to activities of internal nitrogen metabolism-related enzymes, related gene expression and reductant supply, and external environmental factor regulation (Figure 2). To reduce the nitrate concentration and concomitantly maintain or increase vegetable yields and nutrition quality, different nitrate regulatory strategies should be considered when regulating the nitrate concentration in vegetables. Environmentally controlled facilities such as greenhouses and closed-type plant factories provide great convenience for the regulation of nitrate concentration in vegetables. However, additional detailed studies about the following aspects are still needed in terms of decreasing nitrates in vegetables produced in controlled environments:

(1) Nitrate uptake and assimilation are coordinated with photosynthetic carbon fixation in different dynamic environments [44]. The transcription factor HY5/HYH plays a core role in the complex network of nitrate assimilation and photosynthesis in plants [59]. However, the current knowledge is insufficient, and additional studies are still needed to clarify the molecular mechanism by which $\mathrm{HY} 5 / \mathrm{HYH}$ regulates nitrate uptake, distribution, and assimilation under different conditions in protected facilities. An improved understanding of $\mathrm{HY} 5 / \mathrm{HYH}$ function and signaling could provide more useful information for improving nitrogen-use efficiency and producing low-nitrate vegetables in controlled environments;

(2) It is well known that suitable light conditions are one of the key environmental factors that ensure a relatively high yield and improve nutritional quality. The effects of light spectra on nitrate uptake, assimilation, and distribution are affected by the concentration of some of the 
micro-elements (e.g., selenium and $\mathrm{Cl}^{-1}$ ) in the nutrition solution/soil and by other environmental factors. For instance, an optimal percentage of red light in light spectra (also known as light recipes) combined with exogenous application of selenium can produce selenium-enriched lettuce with low nitrate concentration [148]. Therefore, when combined with other suitable environmental factors (e.g., micro-elements, temperature, and $\mathrm{CO}_{2}$ ), an optimal light recipe provided by LED light can achieve targeted regulation of nutritional quality and yield of vegetables;

(3) Overfertilization with nitrate is the main reason for excessive nitrate accumulation in crops and other related environmental pollution. Precision management of nutrient elements based on plant growth requirements can pave a new way to increase crop yield, nutrition quality, and concomitantly increase fertilizer-use efficiency. The rapid development of high-throughput genomic technology has enabled biology to enter the era of large datasets ('big data') [149]. Future research regarding machine learning with 'big data' technology will provide an opportunity for plant scientists to develop precision nitrate fertilizer strategies according to the nitrate requirement of crops at different growth stages, thereby producing leafy vegetables with a low nitrate concentration in controlled environments.

Author Contributions: Conceptualization, Z.B., Q.Y. and R.C.; writing-original draft preparation, Z.B., Y.W., and X.Z.; writing-review and editing, Z.B., R.C., T.L., Q.Y., and S.G.; supervision, Q.Y. and R.C.; funding acquisition, Q.Y. and R.C. All authors have read and agreed to the published version of the manuscript.

Funding: This research was funded by the Science and Technology Innovation Program of the Chinese Academy of Agricultural Sciences, the Central Public-Interest Scientific Institution Basal Research Fund (No. Y2020XK01 and No. Y2020XK02), and local financial funding from the National Agriculture Science and Technology Center, Chengdu (NASC2019AR01).

Acknowledgments: We thank Caroline Howells and Andrew Moss for the language editing of this manuscript.

Conflicts of Interest: The authors declare that there are no conflicts of interest.

\section{References}

1. Crawford, N.M. Nitrate: Nutrient and signal for plant growth. Plant Cell 1995, 7, 859. [PubMed]

2. Agostini, F.; Tei, F.; Silgram, M.; Farneselli, M.; Benincasa, P.; Aller, M. Decreasing nitrate leaching in vegetable crops with better N management. In Genetic Engineering, Biofertilisation, Soil Quality and Organic Farming; Springer: Berlin, Germany, 2010; pp. 147-200.

3. Ju, X.T.; Xing, G.X.; Chen, X.P.; Zhang, S.L.; Zhang, L.J.; Liu, X.J.; Cui, Z.L.; Yin, B.; Christie, P.; Zhu, Z.L. Reducing environmental risk by improving $\mathrm{N}$ management in intensive Chinese agricultural systems. Proc. Natl. Acad. Sci. USA 2009, 106, 3041-3046. [CrossRef] [PubMed]

4. Sutton, M.A.; Bleeker, A.; Howard, C.M.; Bekunda, M.; Grizzetti, B.; de Vries, W.; van Grinsven, H.J.M.; Abrol, Y.P.; Adhya, T.K.; Billen, G.; et al. Our Nutrient World: The Challenge to Produce More Food and Energy with Less Pollution. Global Overview of Nutrient Management; Centre for Ecology and Hydrology on behalf of the Global Partnership on Nutrient Management and the International Nitrogen Initiative: Edinburgh, UK, 2013.

5. Bian, Z.H.; Yang, Q.C.; Liu, W.K. Effects of light quality on the accumulation of phytochemicals in vegetables produced in controlled environments: A review. J. Sci. Food Agric. 2015, 95, 869-877. [CrossRef] [PubMed]

6. Bian, Z.H.; Cheng, R.F.; Yang, Q.C.; Wang, J.; Lu, C.G. Continuous light from red, blue, and green light-emitting diodes reduces nitrate concentration and enhances phytochemical concentrations and antioxidant capacity in lettuce. J. Am. Soc. Hortic. Sci. 2016, 141, 186-195. [CrossRef]

7. Xu, G.; Fan, X.; Miller, A.J. Plant nitrogen assimilation and use efficiency. Annu. Rev. Plant Biol. 2012, 63, 153-182. [CrossRef]

8. Ashworth, A.; Mitchell, K.; Blackwell, J.R.; Vanhatalo, A.; Jones, A.M. High-nitrate vegetable diet increases plasma nitrate and nitrite concentrations and reduces blood pressure in healthy women. Public Health Nutr. 2015, 18, 2669-2678. [CrossRef]

9. Ashworth, A.; Bescos, R. Dietary nitrate and blood pressure: Evolution of a new nutrient? Nutr. Res. Rev. 2017, 30, 208-219. [CrossRef]

10. Chan, T.Y. Vegetable-borne nitrate and nitrite and the risk of methaemoglobinaemia. Toxicol. Lett. 2011, 200, 107-108. [CrossRef] 
11. Song, P.; Wu, L.; Guan, W. Dietary nitrates, nitrites, and nitrosamines intake and the risk of gastric cancer: A meta-analysis. Nutrients 2015, 7, 9872-9895. [CrossRef]

12. Joint FAO/WHO Expert Committee on Food Additives (JECFA). Evaluation of Certain Food Additives and Contaminants: Eightieth Report of the Joint FAO/WHO Expert Committee on Food Additives; World Health Organization (WHO): Geneva, Switzerland, 2016; Volume 995, p. 132.

13. Van Velzen, A.G.; Sips, A.J.A.M.; Schothorst, R.C.; Lambers, A.C.; Meulenbelt, J. The oral bioavailability of nitrate from nitrate-rich vegetables in humans. Toxicol. Lett. 2008, 181, 177-181. [CrossRef]

14. Bian, Z.H.; Cheng, R.C.; Wang, Y.; Yang, Q.C.; Lu, C.G. Effect of green light on nitrate reduction and edible quality of hydroponically grown lettuce (Lactuca sativa L.) under short-term continuous light from red and blue light-emitting diodes. Environ. Exp. Bot. 2018, 153, 63-71. [CrossRef]

15. Colonna, E.; Rouphael, Y.; Barbieri, G.; De Pascale, S. Nutritional quality of ten leafy vegetables harvested at two light intensities. Food Chem. 2016, 199, 702-710. [CrossRef] [PubMed]

16. Lin, K.H.; Huang, M.Y.; Huang, W.D.; Hsu, M.H.; Yang, Z.W.; Yang, C.M. The effects of red, blue, and white light-emitting diodes on the growth, development, and edible quality of hydroponically grown lettuce (Lactuca sativa L. var. capitata). Sci. Hortic. 2013, 150, 86-91. [CrossRef]

17. Lam, H.M.; Coschigano, K.T.; Oliveira, I.C.; Melo-Oliveira, R.; Coruzzi, G.M. The molecular-genetics of nitrogen assimilation into amino acids in higher plants. Annu. Rev. Plant. Biol. 1996, 47, 569-593. [CrossRef] [PubMed]

18. Hickman, G. International greenhouse vegetable production-statistics. In A Review of Currently Available Data on the International Production of Vegetables in Greenhouses; Cuesta roble greenhouse consultants: Mariposa, CA, USA, 2016.

19. Sabir, N.; Singh, B. Protected cultivation of vegetables in global arena: A review. Indian J. Agric. Sci. 2013, 83, 123-135.

20. Khan, F.A. A review on hydroponic greenhouse cultivation for sustainable agriculture. Int. J. Agric. Environ. Food Sci. 2018, 2, 59-66. [CrossRef]

21. Anjana, S.U.; Iqbal, M. Nitrate accumulation in plants, factors affecting the process, and human health implications. A review. Agron. Sustain. Dev. 2007, 27, 45-57. [CrossRef]

22. Bindraban, P.S.; Dimkpa, C.; Nagarajan, L.; Roy, A.; Rabbinge, R. Revisiting fertilisers and fertilisation strategies for improved nutrient uptake by plants. Biol. Fertil. Soils 2015, 51, 897-911. [CrossRef]

23. Gruda, N. Impact of environmental factors on product quality of greenhouse vegetables for fresh consumption. Crit. Rev. Plant Sci. 2005, 24, 227-247. [CrossRef]

24. Wang, Y.Y.; Tsay, Y.F. Arabidopsis nitrate transporter NRT1.9 is important in phloem nitrate transport. Plant Cell 2011, 23, 1945-1957. [CrossRef]

25. Iglesias-Bartolomé, R.; González, C.A.; Kenis, J.D. Nitrate reductase dephosphorylation is induced by sugars and sugar-phosphates in corn leaf segments. Physiol. Plant. 2004, 122, 62-67. [CrossRef]

26. Busch, F.A.; Sage, R.F.; Farquhar, G.D. Plants increase $\mathrm{CO}_{2}$ uptake by assimilating nitrogen via the photorespiratory pathway. Nat. Plants 2018, 4, 46. [CrossRef] [PubMed]

27. Ruan, Y.L.; Jin, Y.; Yang, Y.J.; Li, G.J.; Boyer, J.S. Sugar input, metabolism, and signaling mediated by invertase: Roles in development, yield potential, and response to drought and heat. Mol. Plant 2010, 3, 942-955. [CrossRef]

28. Miller, A.J.; Fan, X.; Orsel, M.; Smith, S.J.; Wells, D.M. Nitrate transport and signalling. J. Exp. Bot. 2007, 58, 2297-2306. [CrossRef]

29. Walker, B.J.; Strand, D.D.; Kramer, D.M.; Cousins, A.B. The response of cyclic electron flow around photosystem I to changes in photorespiration and nitrate assimilation. Plant Physiol. 2014, 165, 453-462. [CrossRef]

30. Van der Boon, J.; Steenhuizen, J.; Steingrover, E.G. Growth and nitrate concentration of lettuce as affected by total nitrogen and chloride concentration, $\mathrm{NH}_{4} / \mathrm{NO}_{3}$ ratio and temperature of the recirculating nutrient solution. J. Hortic. Sci. 1990, 65, 309-321. [CrossRef]

31. Nieuwhof, M. Effects of temperature and light on nitrate content of radish (Raphanus sativus L.). Gartenbauwissenschaft 1995, 59, 220-224.

32. Gangappa, S.N.; Botto, J.F. The multifaceted roles of HY5 in plant growth and development. Mol. Plant 2016, 9, 1353-1365. [CrossRef] 
33. Osterlund, M.T.; Hardtke, C.S.; Wei, N.; Deng, X.W. Targeted destabilization of HY5 during light-regulated development of Arabidopsis. Nature 2000, 405, 462-466. [CrossRef]

34. Calatayud, Á.; Gorbe, E.; Roca, D.; Martínez, P.F. Effect of two nutrient solution temperatures on nitrate uptake, nitrate reductase activity, $\mathrm{NH}_{4}{ }^{+}$concentration and chlorophyll a fluorescence in rose plants. Environ. Exp. Bot. 2008, 64, 65-74. [CrossRef]

35. Gent, M.P.N. Effect of degree and duration of shade on quality of greenhouse tomato. Hortscience 2007, 42, 514-520. [CrossRef]

36. Demšar, J.; Osvald, J.; Vodnik, D. The effect of light-dependent application of nitrate on the growth of aeroponically grown lettuce (Lactuca sativa L.). J. Am. Soc. Hortic. Sci. 2004, 129, 570-575. [CrossRef]

37. Fu, Y.; Li, H.; Yu, J.; Liu, H.; Cao, Z.; Manukovsky, N.; Liu, H. Interaction effects of light intensity and nitrogen concentration on growth, photosynthetic characteristics and quality of lettuce (Lactuca sativa L. Var. youmaicai). Sci. Hortic. 2017, 214, 51-57. [CrossRef]

38. Zheng, Y.J.; Zhang, Y.T.; Liu, H.C.; Li, Y.M.; Liu, Y.L.; Hao, Y.W.; Lei, B.F. Supplemental blue light increases growth and quality of greenhouse pak choi depending on cultivar and supplemental light intensity. J. Integr. Agric. 2018, 17, 2245-2256. [CrossRef]

39. Samuolienè, G.; Brazaitytè, A.; Jankauskienè, J.; Viršilè, A.; Sirtautas, R.; Novičkovas, A.; Sakalauskienè, S.; Sakalauskaitè, J.; Duchovskis, P. LED irradiance level affects growth and nutritional quality of Brassica microgreens. Open Life Sci. 2013, 8, 1241-1249. [CrossRef]

40. Perez-Lopez, U.; Miranda-Apodaca, J.; Munoz-Rueda, A.; Mena-Petite, A. Interacting effects of high light and elevated $\mathrm{CO}_{2}$ on the nutraceutical quality of two differently pigmented Lactuca sativa cultivars (Blonde of Paris Batavia and Oak Leaf). Sci. Hortic. 2015, 191, 38-48. [CrossRef]

41. Jonassen, E.M.; Lea, U.S.; Lillo, C. HY5 and HYH are positive regulators of nitrate reductase in seedlings and rosette stage plants. Planta 2008, 227, 559-564. [CrossRef]

42. Fait, A.; Sienkiewicz-Porzucek, A.; Fernie, A.R. Metabolomics approaches to advance understanding of nitrogen assimilation and carbon-nitrogen interactions. Annu. Plant Rev. Online 2018, 6, 249-268.

43. An, J.P.; Qu, F.J.; Yao, J.F.; Wang, X.N.; You, C.X.; Wang, X.F.; Hao, Y.J. The bZIP transcription factor MdHY5 regulates anthocyanin accumulation and nitrate assimilation in apple. Hortic. Res. 2017, 4, 17023. [CrossRef]

44. Chen, X.; Yao, Q.; Gao, X.; Jiang, C.; Harberd, N.P.; Fu, X. Shoot-to-root mobile transcription factor HY5 coordinates plant carbon and nitrogen acquisition. Curr. Biol. 2016, 26, 640-646. [CrossRef]

45. Lillo, C. Signalling cascades integrating light-enhanced nitrate metabolism. Biochem. J. 2008, 415, 11-19. [CrossRef] [PubMed]

46. Nunes-Nesi, A.; Fernie, A.R.; Stitt, M. Metabolic and signaling aspects underpinning the regulation of plant carbon nitrogen interactions. Mol. Plant 2010, 3, 973-996. [CrossRef] [PubMed]

47. Burns, I.G.; Zhang, K.; Turner, M.K.; Edmondson, R. Iso-osmotic regulation of nitrate accumulation in lettuce. J. Plant Nutr. 2010, 34, 283-313. [CrossRef]

48. Li, Y.; Chang, D.; Yang, H.; Wang, J.; Shi, H. Metabolome and molecular basis for carbohydrate increase and nitrate reduction in burley tobacco seedlings by glycerol through upregulating carbon and nitrogen metabolism. Sci. Rep. 2018, 8, 13300. [CrossRef]

49. Cheung, C.M.; Poolman, M.G.; Fell, D.A.; Ratcliffe, R.G.; Sweetlove, L.J. A diel flux balance model captures interactions between light and dark metabolism during day-night cycles in C3 and crassulacean acid metabolism leaves. Plant Physiol. 2014, 165, 917-929. [CrossRef]

50. Tegeder, M.; Masclaux-Daubresse, C. Source and sink mechanisms of nitrogen transport and use. New Phytol. 2018, 217, 35-53. [CrossRef]

51. He, Y.N.; Peng, J.S.; Cai, Y.; Liu, D.F.; Guan, Y.; Yi, H.Y.; Gong, J.M. Tonoplast-localized nitrate uptake transporters involved in vacuolar nitrateefflux and reallocation in Arabidopsis. Sci. Rep. 2017, 7, 6417. [CrossRef]

52. Neely, H.L.; Koenig, R.T.; Miles, C.A.; Koenig, T.C.; Karlsson, M.G. Diurnal fluctuation in tissue nitrate concentration of field-grown leafy greens at two latitudes. Hort Sci. 2010, 45, 1815-1818. [CrossRef]

53. Zhou, W.; Liu, W.; Yang, Q. Quality changes in hydroponic lettuce grown under pre-harvest short-duration continuous light of different intensities. J. Hortic. Sci. Biotechnol. 2012, 87, 429-434. [CrossRef]

54. Jonassen, E.M.; Sandsmark, B.A.; Lillo, C. Unique status of NIA2 in nitrate assimilation: NIA2 expression is promoted by HY5/HYH and inhibited by PIF4. Plant Signal. Behav. 2009, 4, 1084-1086. [CrossRef] 
55. Jonassen, E.M.; Sévin, D.C.; Lillo, C. The bZIP transcription factors HY5 and HYH are positive regulators of the main nitrate reductase gene in Arabidopsis leaves, NIA2, but negative regulators of the nitrate uptake gene NRT1.1. J. Plant Physiol. 2009, 166, 2071-2076. [CrossRef]

56. Meyer, C.; Lea, U.S.; Provan, F.; Kaiser, W.M.; Lillo, C. Is nitrate reductase a major player in the plant NO (nitric oxide) game? Photosynth. Res. 2005, 83, 181-189. [CrossRef]

57. Krapp, A. Plant nitrogen assimilation and its regulation: A complex puzzle with missing pieces. Curr. Opin. Plant Biol. 2015, 25, 115-122. [CrossRef]

58. Maevskaya, S.; Bukhov, N. Effect of light quality on nitrogen metabolism of radish plants. Russ. J. Plant Physiol. 2005, 52, 304-310. [CrossRef]

59. Sakuraba, Y.; Yanagisawa, S. Light signalling-induced regulation of nutrient acquisition and utilisation in plants. Semin. Cell Dev. Biol. 2018, 83, 123-132. [CrossRef]

60. Chang, C.L.; Chang, K.P. The growth response of leaf lettuce at different stages to multiple wavelength-band light-emitting diode lighting. Sci. Hortic. 2014, 179, 78-84. [CrossRef]

61. Brazaitytè, A.; Viršile, A.; Jankauskiene, J.; Sakalauskiene, S.; Samuoliene, G.; Sirtautas, R.; Novičkovas, A.; Dabašinskas, L.; Miliauskiene, J.; Vaštakaite, V.; et al. Effect of supplemental UV-A irradiation in solid-state lighting on the growth and phytochemical content of microgreens. Int. Agrophysics 2015, 29, 13-22. [CrossRef]

62. Chen, X.; Xue, X.Z.; Guo, W.; Wang, L.; Qiao, X. Growth and nutritional properties of lettuce affected by mixed irradiation of white and supplemental light provided by light-emitting diode. Sci. Hortic. 2016, 200, 111-118. [CrossRef]

63. Samuolienè, G.; Brazaitytè, A.; Sirtautas, R.; Novičkovas, A.; Duchovskis, P. The effect of supplementary LED lighting on the antioxidant and nutritional properties of lettuce. Acta Hortic. 2012, 952, 835-841. [CrossRef]

64. Bliznikas, Z.; Žukauskas, A.; Samuoliene, G.; Viršile, A.; Brazaityte, A.; Jankauskiene, J.; Duchovskis, P.; Novičkovas, A. Effect of supplementary pre-harvest LED lighting on the antioxidant and nutritional properties of green vegetables. Acta Hortic. 2012, 939, 85-91. [CrossRef]

65. Johnson, C.F.; Langhans, R.W.; Albright, L.D.; Combs, G.F.; Welch, R.M.; Heller, L.; Glahn, R.P.; Wheeler, R.M.; Goins, G.D. Spinach: Nitrate analysis of an advanced life support (ALS) crop cultured under ALS candidate artificial light sources. SAE Tech. Paper 1999, 1-5. [CrossRef]

66. Han, X.; Tohge, T.; Lalor, P.; Dockery, P.; Devaney, N.; Esteves-Ferreira, A.A.; Fernie, A.R.; Sulpice, R. Phytochrome A and B regulate primary metabolism in Arabidopsis leaves in response to light. Front. Plant Sci. 2017, 8, 1394. [CrossRef]

67. Monostori, I.; Heilmann, M.; Kocsy, G.; Rakszegi, M.; Ahres, M.; Altenbach, S.; Szalai, G.; Pál, M.; Toldi, D.; Simon-Sarkadi, L. LED lighting-modification of growth, metabolism, yield and flour composition in wheat by spectral quality and intensity. Front. Plant Sci. 2018, 9, 605. [CrossRef]

68. Lillo, C.; Appenroth, K.J. Light regulation of nitrate reductase in higher plants: Which photoreceptors are involved? Plant Biol. 2001, 3, 455-465. [CrossRef]

69. Appenroth, K.J.; Meço, R.; Jourdan, V.; Lillo, C. Phytochrome and post-translational regulation of nitrate reductase in higher plants. Plant Sci. 2000, 159, 51-56. [CrossRef]

70. Chandok, M.R.; Sopory, S.K. Phosphorylation/dephosphorylation steps are key events in the phytochrome-mediated enhancement of nitrate reductase mRNA levels and enzyme activity in maize. Mol. Gen. Genet. 1996, 251, 599-608. [CrossRef]

71. Qi, L.; Liu, S.; Xu, L.; Yu, W.; Liang, Q.; Hao, S. Effects of light qualities on accumulation of oxalate, tannin and nitrate in spinach. Trans. Chin. Soc. Agric. Eng. 2007, 23, 201-205.

72. Osterlund, M.T.; Wei, N.; Deng, X.W. The roles of photoreceptor systems and the COP1-targeted destabilization of HY5 in light control of Arabidopsis seedling development. Plant Physiol. 2000, 124, 1520-1524. [CrossRef]

73. Castillon, A.; Shen, H.; Huq, E. Blue light induces degradation of the negative regulator phytochrome interacting factor 1 to promote photomorphogenic development of Arabidopsis seedlings. Genetics 2009, 182, 161-171. [CrossRef]

74. Kaur, G.; Asha, W.; Abdin, M.Z.; Sarwat, M.; Ahmad, A.I. Molecular network of nitrogen and sulphur signaling in plants. In Stress Signaling in Plants: Genomics and Proteomics Perspective, 1st ed.; Sarwat, M., Ahmad, A., Ahmad, M.Z., Eds.; Springer: New York, NY, USA, 2013; p. 240.

75. Sysoeva, M.I.; Markovskaya, E.F.; Shibaeva, T.G. Plants under continuous light: A review. Plant Stress 2010, 4, 5-17. 
76. O'Connor, D.J.; Wright, G.C.; Dieters, M.J.; George, D.L.; Hunter, M.N.; Tatnell, J.R.; Fleischfresser, D.B. Development and application of speed breeding technologies in a commercial peanut breeding program. Peanut Sci. 2013, 40, 107-114. [CrossRef]

77. Velez-Ramirez, A.I.; van Ieperen, W.; Vreugdenhil, D.; Millenaar, F.F. Plants under continuous light. Trends Plant Sci. 2011, 16, 310-318. [CrossRef]

78. Bian, Z.H.; Yang, Q.C.; Li, T.; Cheng, R.F.; Barnett, Y.; Lu, C.G. Study of the beneficial effects of green light on lettuce grown under short-term continuous red and blue light-emitting diodes. Physiol. Plant. 2018, 164, 226-240. [CrossRef] [PubMed]

79. Bian, Z.H.; Zhang, X.Y.; Wang, Y.; Lu, C.G. Improving drought tolerance by altering the photosynthetic rate and stomatal aperture via green light in tomato (Solanum lycopersicum L.) seedlings under drought conditions. Environ. Exp. Bot. 2019, 167, 103844. [CrossRef]

80. Wargent, J.J.; Elfadly, E.M.; Moore, J.P.; Paul, N.D. Increased exposure to UV-B radiation during early development leads to enhanced photoprotection and improved long-term performance in Lactuca sativa. Plant Cell Environ. 2011, 34, 1401-1413. [CrossRef] [PubMed]

81. Schreiner, M.; Martínez-Abaigar, J.; Glaab, J.; Jansen, M. UV-B induced secondary plant metabolites: Potential benefits for plant and human health. Opt. Photonik 2014, 9, 34-37. [CrossRef]

82. Xu, J.; Gao, K. UV-A enhanced growth and UV-B induced positive effects in the recovery of photochemical yield in Gracilaria lemaneiformis (Rhodophyta). J. Photochem. Photobiol. B Biol. 2010, 100, 117-122. [CrossRef]

83. $\mathrm{Xu}, \mathrm{K} . ;$ radiation. Plant Sci. 2007, 172, 139-149. [CrossRef]

84. Jansen, M.A.; Gaba, V.; Greenberg, B.M. Higher plants and UV-B radiation: Balancing damage, repair and acclimation. Trends Plant Sci. 1998, 3, 131-135. [CrossRef]

85. Kataria, S.; Jajoo, A.; Guruprasad, K.N. Impact of increasing Ultraviolet-B (UV-B) radiation on photosynthetic processes. J. Photochem. Photobiol. B Biol. 2014, 137, 55-66. [CrossRef]

86. Krause, G.H.; Gallé, A.; Gademann, R.; Winter, K. Capacity of protection against ultraviolet radiation in sun and shade leaves of tropical forest plants. Funct. Plant Biol. 2003, 30, 533-542. [CrossRef]

87. Takahashi, S.; Milward, S.E.; Yamori, W.; Evans, J.R.; Hillier, W.; Badger, M.R. The solar action spectrum of photosystem II damage. Plant Physiol. 2010, 153, 988-993. [CrossRef]

88. Bashri, G.; Singh, M.; Mishra, R.K.; Kumar, J.; Singh, V.P.; Prasad, S.M. Kinetin regulates UV-B-induced damage to growth, photosystem II photochemistry, and nitrogen metabolism in tomato seedlings. J. Plant Growth Regul. 2018, 37, 233-245. [CrossRef]

89. Huang, G.; Wang, L.; Zhou, Q. Lanthanum (III) regulates the nitrogen assimilation in soybean seedlings under ultraviolet-B radiation. Bio. Trace Elem. Res. 2013, 151, 105-112. [CrossRef] [PubMed]

90. Schwalbe, M.; Teller, S.; Oelmüller, R.; Appenroth, K.J. Influence of UVB irradiation on nitrate and ammonium assimilating enzymes in Spirodela polyrhiza. Aquat. Bot. 1999, 64, 19-34. [CrossRef]

91. Ulm, R.; Baumann, A.; Oravecz, A.; Máté, Z.; Ádám, É; Oakeley, E.J.; Schäfer, E.; Nagy, F. Genome-wide analysis of gene expression reveals function of the bZIP transcription factor HY5 in the UV-B response of Arabidopsis. Proc. Natl. Acad. Sci. USA 2004, 101, 1397-1402. [CrossRef]

92. Cloix, C.; Kaiserli, E.; Heilmann, M.; Baxter, K.J.; Brown, B.A.; O'Hara, A.; Smith, B.O.; Christie, J.M.; Jenkins, G.I. C-terminal region of the UV-B photoreceptor UVR8 initiates signaling through interaction with the COP1 protein. Proc. Natl. Acad. Sci. USA 2012, 109, 16366-16370. [CrossRef]

93. Wang, Y.Y.; Cheng, Y.H.; Chen, K.E.; Tsay, Y.F. Nitrate transport, signaling, and use efficiency. Annu. Rev. Plant Biol. 2018, 69, 85-122. [CrossRef]

94. He, J.; Austin, P.T.; Lee, S.K. Effects of elevated root zone $\mathrm{CO}_{2}$ and air temperature on photosynthetic gas exchange, nitrate uptake, and total reduced nitrogen concentration in aeroponically grown lettuce plants. J. Exp. Bot. 2010, 61, 3959-3969. [CrossRef]

95. Peet, M.; Sato, S.; Clément, C.; Pressman, E. Heat stress increases sensitivity of pollen, fruit and seed production in tomatoes (Lycopersicon esculentum Mill.) to non-optimal vapor pressure deficits. Acta Hortic. 2003, 618, 209-215. [CrossRef]

96. Toivonen, P.M. Postharvest physiology of vegetables. In Handbook of Vegetables and Vegetable Processing; Sinha, N., Hui, Y.H., Evranuz, E.Ö., Siddiq, M., Ahmed, J., Eds.; Wiley-Blackwell Publishing: Oxford, UK, 2010; pp. 199-220. ISBN 978-0-8138-1541-1. 
97. Klimenko, S.; Peshkova, A.; Dorofeev, N. Nitrate reductase activity during heat shock in winter wheat. J. Stress Physiol. Biochem. 2006, 2, 50-55.

98. Shu, S.; Tang, Y.; Yuan, Y.; Sun, J.; Zhong, M.; Guo, S. The role of 24-epibrassinolide in the regulation of photosynthetic characteristics and nitrogen metabolism of tomato seedlings under a combined low temperature and weak light stress. Plant Physiol. Biochem. 2016, 107, 344-353. [CrossRef]

99. Li, W.; Wang, Y.; Okamoto, M.; Crawford, N.M.; Siddiqi, M.Y.; Glass, A.D. Dissection of the AtNRT2.1:AtNRT2.2 inducible high-affinity nitrate transporter gene cluster. Plant Physiol. 2007, 143, 425-433. [CrossRef]

100. Orsel, M.; Chopin, F.; Leleu, O.; Smith, S.J.; Krapp, A.; Daniel-Vedele, F.; Miller, A.J. Characterization of a two-component high-affinity nitrate uptake system in Arabidopsis. Physiology and protein-protein interaction. Plant Physiol. 2006, 142, 1304-1317. [CrossRef]

101. Goel, P.; Singh, A.K. Abiotic stresses downregulate key genes involved in nitrogen uptake and assimilation in Brassica juncea L. PLoS ONE 2015, 10, e0143645. [CrossRef]

102. Catalá, R.; Medina, J.; Salinas, J. Integration of low temperature and light signaling during cold acclimation response in Arabidopsis. Proc. Natl. Acad. Sci. USA 2011, 108, 16475-16480. [CrossRef]

103. Karayekov, E.; Sellaro, R.; Legris, M.; Yanovsky, M.J.; Casal, J.J. Heat shock-induced fluctuations in clock and light signaling enhance phytochrome B-mediated arabidopsis deetiolation. Plant Cell 2013, 25, 2892-2906. [CrossRef]

104. Bloom, A.J.; Asensio, J.S.R.; Randall, L.; Rachmilevitch, S.; Cousins, A.B.; Carlisle, E.A. $\mathrm{CO}_{2}$ enrichment inhibits shoot nitrate assimilation in $C_{3}$ but not $C_{4}$ plants and slows growth under nitrate in $C_{3}$ plants. Ecology 2012, 93, 355-367. [CrossRef]

105. Natali, S.M.; Sañudo-Wilhelmy, S.A.; Lerdau, M.T. Effects of elevated carbon dioxide and nitrogen fertilization on nitrate reductase activity in sweetgum and loblolly pine trees in two temperate forests. Plant Soil 2009, 314, 197-210. [CrossRef]

106. White, A.C.; Rogers, A.; Rees, M.; Osborne, C.P. How can we make plants grow faster? A source-sink perspective on growth rate. J. Exp. Bot. 2016, 67, 31-45. [CrossRef]

107. Dong, J.; Gruda, N.; Lam, S.K.; Li, X.; Duan, Z. Effects of elevated $\mathrm{CO}_{2}$ on nutritional quality of vegetables: A Review. Front. Plant Sci. 2018, 9, 9. [CrossRef]

108. Piñero, M.C.; Pérez-Jiménez, M.; López-Marín, J.; del Amor, F.M. Changes in the salinity tolerance of sweet pepper plants as affected by nitrogen form and high $\mathrm{CO}_{2}$ concentration. J. Plant Physiol. 2016, 200, 18-27. [CrossRef]

109. Robredo, A.; Pérez-López, U.; Miranda-Apodaca, J.; Lacuesta, M.; Mena-Petite, A.; Muñoz-Rueda, A. Elevated $\mathrm{CO}_{2}$ reduces the drought effect on nitrogen metabolism in barley plants during drought and subsequent recovery. Environ. Exp. Bot. 2011, 71,399-408. [CrossRef]

110. Larios, B.; Agüera, E.; de la Haba, P.; Pérez-Vicente, R.; Maldonado, J.M. A short-term exposure of cucumber plants to rising atmospheric $\mathrm{CO}_{2}$ increases leaf carbohydrate concentration and enhances nitrate reductase expression and activity. Planta 2001, 212, 305-312. [CrossRef]

111. Stitt, M.; Krapp, A. The interaction between elevated carbon dioxide and nitrogen nutrition: The physiological and molecular background. Plant Cell Environ. 1999, 22, 583-621. [CrossRef]

112. Bloom, A.J.; Burger, M.; Kimball, B.A.; Pinter, P.J., Jr. Nitrate assimilation is inhibited by elevated $\mathrm{CO}_{2}$ in field-grown wheat. Nat. Clim. Chang. 2014, 4, 477. [CrossRef]

113. Stitt, M. Limitation of photosynthesis by carbon metabolism: I. Evidence for excess electron transport capacity in leaves carrying out photosynthesis in saturating light and $\mathrm{CO}_{2}$. Plant Physiol. 1986, 81, 1115-1122. [CrossRef] [PubMed]

114. Bloom, A.J.; Smart, D.R.; Nguyen, D.T.; Searles, P.S. Nitrogen assimilation and growth of wheat under elevated carbon dioxide. Proc. Natl. Acad. Sci. USA 2002, 99, 1730-1735. [CrossRef]

115. Matallana González, M.; Martínez-Tomé, M.; Torija Isasa, M. Nitrate and nitrite concentration in organically cultivated vegetables. Food Addit. Contam. Part B 2010, 3, 19-29. [CrossRef] [PubMed]

116. Lal, R. Feeding 11 billion on 0.5 billion hectare of area under cereal crops. Food Energy Secur. 2016, 5, $239-251$. [CrossRef]

117. Zhao, C.; Liu, B.; Piao, S.; Wang, X.; Lobell, D.B.; Huang, Y.; Huang, M.; Yao, Y.; Bassu, S.; Ciais, P. Temperature increase reduces global yields of major crops in four independent estimates. Proc. Natl. Acad. Sci. USA 2017, 114, 9326-9331. [CrossRef] [PubMed] 
118. Liu, W.K.; Yang, Q.C. Effects of short-term treatment with various light intensities and hydroponic solutions on nitrate concentration of lettuce. Acta Agric. Scand. Sect. B -Soil Plant Sci. 2012, 62, 109-113. [CrossRef]

119. Liu, W.K.; Yang, Q.C.; Du, L.F. Short-term treatment with hydroponic solutions containing osmotic ions and ammonium molybdate decreased nitrate concentration in lettuce. Acta Agric. Scand. Sect. B -Soil Plant Sci. 2011, 61, 573-576. [CrossRef]

120. Wang, B.; Shen, $\mathrm{Q}$. $\mathrm{NH}_{4}{ }^{+}-\mathrm{N} / \mathrm{NO}_{3}{ }^{-}-\mathrm{N}$ ratios on growth and $\mathrm{NO}_{3}{ }^{-}-\mathrm{N}$ remobilization in root vacuoles and cytoplasm of lettuce genotypes. Can. J. Plant Sci. 2011, 91, 411-417. [CrossRef]

121. Lin, X.Y.; Liu, X.X.; Zhang, Y.P.; Zhou, Y.Q.; Hu, Y.; Chen, Q.H.; Zhang, Y.S.; Jin, C.W. Short-term alteration of nitrogen supply prior to harvest affects quality in hydroponic-cultivated spinach (Spinacia oleracea). J. Sci. Food Agric. 2014, 94, 1020-1025. [CrossRef] [PubMed]

122. Urlić, B.; Dumičić, G.; Romić, M.; Ban, S.G. The effect of $\mathrm{N}$ and $\mathrm{NaCl}$ on growth, yield, and nitrate concentration of salad rocket (Eruca sativa Mill.). J. Plant Nutr. 2017, 40, 2611-2618. [CrossRef]

123. Henriques, A.D.P.; Marcelis, L. Regulation of growth at steady-state nitrogen nutrition in lettuce (Lactuca sativa L.): Interactive effects of nitrogen and irradiance. Ann. Bot. 2000, 86, 1073-1080. [CrossRef]

124. Lei, B.; Bian, Z.H.; Yang, Q.C.; Wang, J.; Cheng, R.F.; Li, K.; Liu, W.K.; Zhang, Y.; Fang, H.; Tong, Y.X. The positive function of selenium supplementation on reducing nitrate accumulation in hydroponic lettuce (Lactuca sativa L.). J. Integr. Agric. 2018, 17, 837-846. [CrossRef]

125. Wojciechowska, R.; Kowalska, I. The effect of foliar application of urea, Mo and BA on nitrate metabolism in lettuce leaves in the spring and summer-autumn seasons. Folia Hortic. 2011, 23, 119-123. [CrossRef]

126. Moncada, A.; Miceli, A.; Sabatino, L.; Iapichino, G.; D'Anna, F.; Vetrano, F. Effect of molybdenum rate on yield and quality of lettuce, escarole, and curly endive grown in a floating system. Agronomy 2018, 8, 171. [CrossRef]

127. Kovács, B.; Puskás-Preszner, A.; Huzsvai, L.; Lévaib, L.; Bódi, É. Effect of molybdenum treatment on molybdenum concentration and nitrate reduction in maize seedlings. Plant Physiol. Biochem. 2015, 96, 38-44. [CrossRef] [PubMed]

128. Sabatino, L.; D’Anna, F.; D’Anna, F.; Iapichino, G.; Moncada, A.; D’Anna, E.; De Pasquale, C. Interactive.effects of genotype and molybdenum supply on yield and overall fruit quality of tomato. Front. Plant Sci. 2019, 9, 1922. [CrossRef]

129. Borlotti, A.; Vigani, G.; Zocchi, G. Iron deficiency affects nitrogen metabolism in cucumber (Cucumis sativus L.) plants. BMC Plant Biol. 2012, 12, 189. [CrossRef]

130. Bulgari, R.; Cocetta, G.; Trivellini, A.; Vernieri, P.; Ferrante, A. Biostimulants and crop responses: A review. Biol. Agric. Hortic. 2015, 31, 1-17. [CrossRef]

131. Colla, G.; Rouphael, Y. Biostimulants in horticulture. Sci. Hortic. 2015, 30, 1-2. [CrossRef]

132. Amanda, A.; Ferrante, A.; Valagussa, M.; Piaggesi, A. Effect of biostimulants on quality of baby leaf lettuce grown under plastic tunnel. Acta Hortic. 2019, 807, 407-412. [CrossRef]

133. Kunicki, E.; Grabowska, A.; Sekara, A.; Wojciechowska, R. The effect of cultivar type, time of cultivation, and biostimulant treatment on the yield of spinach (Spinacia oleracea L.). Folia Hortic. 2010, 22, 9-13. [CrossRef]

134. Liu, X.Q.; Ko, K.Y.; Kim, S.H.; Lee, K.S. Effect of amino acid fertilization on nitrate assimilation of leafy radish and soil chemical properties in high nitratesoil. Commun. Soil Sci. Plant Anal. 2008, 39, 269-281. [CrossRef]

135. Liu, X.Q.; Lee, K.S. Effect of mixed amino acids on crop growth. In Agricultural Science; Aflakpui, G., Ed.; Tech Europe Publisher: Rijeka, Croatia, 2012; pp. 119-158.

136. Raigon, M. Comparación de parámetros de calidad en hortalizas de hoja ancha bajo sistemas de producción ecológica y convencional. Agrícola vergel Frutic. Hortic. Floric. 2002, 241, $26-32$.

137. Ma, B.L.; Biswas, D.K. Precision nitrogen management for sustainable corn production. In Sustainable Agriculture Reviews; Lichtfouse, E., Goyal, A., Eds.; Springer: Dordrecht, The Netherlands, 2015; pp. $33-62$.

138. Rogovska, N.; Laird, D.A.; Chiou, C.P.; Bond, L.J. Development of field mobile soil nitrate sensor technology to facilitate precision fertilizer management. Precis. Agric. 2019, 20, 40-55. [CrossRef]

139. Schiattone, M.I.; Viggiani, R.; Di Venere, D.; Sergio, L.; Cantore, V.; Todorovic, M.; Perniola, M.; Candido, V. Impact of irrigation regime and nitrogen rate on yield, quality and water use efficiency of wild rocket under greenhouse conditions. Sci. Hortic. 2018, 229, 182-192. [CrossRef]

140. Koyama, R.; Itoh, H.; Kimura, S.; Mirioka, A.; Uno, Y. Augmentation of antioxidant constituents by drought stress to roots in leafy vegetables. Hort Technol. 2012, 22, 121-125. [CrossRef] 
141. Lv, M.C.; Cai, H.J.; Chen, X.M. Effects of sewage irrigation on physiological characteristics of potato and soil environment. J. Irrig. Drain. 2007, 26, 26-29.

142. Al-Lahham, O.; El Assi, N.M.; Fayyad, M. Impact of treated wastewater irrigation on quality attributes and contamination of tomato fruit. Agric. Water Manag. 2003, 61, 51-62. [CrossRef]

143. Yang, B.; Kong, X.; Cui, B.J.; Jin, D.C.; Deng, Y.; Zhuang, X.L.; Zhuang, G.Q.; Bai, Z.H. Impact of rural domestic wastewater irrigation on the physicochemical and microbiological properties of pakchoi and soil. Water 2015, 7, 1825-1839. [CrossRef]

144. Di Mola, I.; Rouphael, Y.; Colla, G.; Fagnano, M.; Paradiso, R.; Mori, M. Morphophysiological traits and nitrate concentration of greenhouse lettuce as affected by irrigation with saline water. HortScience 2017, 52, 1716-1721. [CrossRef]

145. Borgognone, D.Y.; Rouphael, M.; Cardarelli, L.; Lucini, L.1.; Colla, G. Changes in biomass, mineral composition, and quality of cardoon in response to $\mathrm{NO}_{3}{ }^{-}: \mathrm{Cl}^{-}$ratio and nitrate deprivation from the nutrient solution. Front. Plant Sci. 2016, 7, 978. [CrossRef]

146. Li, B.; Byrt, C.S.; Qiu, J.; Baumann, U.; Hrmova, M.; Evrard, A.; Johnson, A.A.; Birnbaum, K.D.; Mayo, G.M.; Jha, D. Identification of a stelar-localized transport protein that facilitates root-to-shoot transfer of chloride in Arabidopsis. Plant Physiol. 2016, 170, 1014-1029. [CrossRef]

147. Li, B.; Qiu, J.; Jayakannan, M.; Xu, B.; Li, Y.; Mayo, G.M.; Tester, M.; Gilliham, M.; Roy, S.J. AtNPF2.5 modulates chloride $\left(\mathrm{Cl}^{-}\right)$efflux from roots of Arabidopsis thaliana. Front. Plant Sci. 2017, 7, 2013. [CrossRef]

148. Bian, Z.H.; Bo, B.; Cheng, R.F.; Wang, Y.; Li, T.; Yang, Q.C. Selenium distribution and nitrate metabolism in hydroponic lettuce (Lactuca sativa L.): Effects of selenium forms and light spectra. J. Integr. Agric. 2020, 19, 133-144. [CrossRef]

149. Ma, C.; Zhang, H.H.; Wang, X. Machine learning for big data analytics in plants. Trends Plant Sci. 2014, 19, 798-808. [CrossRef] [PubMed]

(C) 2020 by the authors. Licensee MDPI, Basel, Switzerland. This article is an open access article distributed under the terms and conditions of the Creative Commons Attribution (CC BY) license (http://creativecommons.org/licenses/by/4.0/). 